CARIM-INDIA - DeVELopING A KNOWLeDGe BASE FOR POLICYMAKING ON INDIA-EU MIGRATION

Co-financed by the European Union

\section{Student Mobility from India to selected European countries The case of Germany and France}

\section{Shahana Mukherjee Rupa Chanda}

CARIM-India Research Report 2012/22

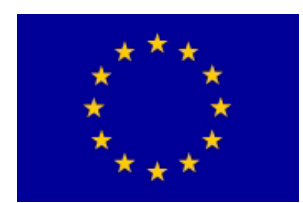


CARIM-India

Developing a knowledge base for policymaking on India-EU migration

Research Report

Thematic Paper

CARIM-India RR 2012/22

\section{Student Mobility from India to selected European countries The case of Germany and France}

\section{Shahana Mukherjee ${ }^{(1)}$ and Rupa Chanda ${ }^{(2)}$}

Doctoral student, Economics and Social Sciences Area, Indian Institute of Management, Bangalore $^{(1)}$;

Professor, Economics and Social Sciences Area, Indian Institute of Management, Bangalore ${ }^{(2)}$ 
This text may be downloaded only for personal research purposes. Any additional reproduction for other purposes, whether in hard copies or electronically, requires the consent of the Robert Schuman Centre for Advanced Studies.

Requests should be addressed to India-EU.Migration@eui.eu

If cited or quoted, reference should be made as follows:

Shahana Mukherjee and Rupa Chanda, Student Mobility from India to selected European countriesThe case of Germany and France, CARIM-India RR 2012/22, Robert Schuman Centre for Advanced Studies, San Domenico di Fiesole (FI): European University Institute, 2012.

THE VIEWS EXPRESSED IN THIS PUBLICATION CANNOT IN ANY CIRCUMSTANCES BE REGARDED AS THE OFFICIAL POSITION OF THE EUROPEAN UNION

\author{
European University Institute \\ Badia Fiesolana \\ I - 50014 San Domenico di Fiesole (FI) \\ Italy \\ http://www.eui.eu/RSCAS/Publications/ \\ http://www.india-eu-migration.eu/publications/ \\ http://cadmus.eui.eu
}




\section{CARIM-India - Developing a knowledge base for policymaking on India-EU migration}

This project is co-financed by the European Union and carried out by the EUI in partnership with the Indian Council of Overseas Employment, (ICOE), the Indian Institute of Management Bangalore Association, (IIMB), and Maastricht University (Faculty of Law).

The proposed action is aimed at consolidating a constructive dialogue between the EU and India on migration covering all migration-related aspects. The objectives of the proposed action are aimed at:

- Assembling high-level Indian-EU expertise in major disciplines that deal with migration (demography, economics, law, sociology and politics) with a view to building up migration studies in India. This is an inherently international exercise in which experts will use standardised concepts and instruments that allow for aggregation and comparison. These experts will belong to all major disciplines that deal with migration, ranging from demography to law and from economics to sociology and political science.

- Providing the Government of India as well as the European Union, its Member States, the academia and civil society, with:

1. Reliable, updated and comparative information on migration

2. In-depth analyses on India-EU highly-skilled and circular migration, but also on low-skilled and irregular migration.

- Making research serve action by connecting experts with both policy-makers and the wider public through respectively policy-oriented research, training courses, and outreach programmes.

These three objectives will be pursued with a view to developing a knowledge base addressed to policy-makers and migration stakeholders in both the EU and India.

Results of the above activities are made available for public consultation through the website of the project: http://www.india-eu-migration.eu/

For more information:

CARIM-India

Robert Schuman Centre for Advanced Studies (EUI)

Convento

Via delle Fontanelle 19

50014 San Domenico di Fiesole

Italy

Tel: +39055 4685817

Fax: + 390554685770

Email: India-EU.Migration@eui.eu

\section{Robert Schuman Centre for Advanced Studies}

http://www.eui.eu/RSCAS/ 


\begin{abstract}
The development of European policies on higher education in the last two decades has facilitated and encouraged (inward) non-European student mobility. This paper examines the issue of student mobility between two European host countries, namely Germany and France and a leading source country, namely India.

Often regarded as the "middle players", the paper identifies factors that drive the demand for higher education in these alternative destinations and elements that have contributed to their growing visibility among Indian students. The paper draws on findings from a recently conducted survey on Indian students in Europe to also identify the challenges associated with pursuing higher education in Germany and France. The paper further examines the role of competition and its impact on the international competitiveness of these destinations and concludes with policy recommendations, which can facilitate international student flows to Germany and France.
\end{abstract}




\section{Introduction}

The last few decades have witnessed the formation of the European Union (EU) and its rise as an influential economic entity, while India has emerged as a global player with strong potential in the key sectors of trade and investment. Both regions actively participate in international trade and a natural consequence of this has been the sustained growth in international relations between India and the EU.

Diplomatic relations between India and the EU have existed since the sixties, though it was the Cooperation Agreement signed in 1994 that set the legal framework for bilateral collaboration and initiated political dialogue in the form of annual summits since 2000. A stronger dimension to this relationship was added in 2004, with the establishment of the India-EU Strategic Partnership. This led to the adoption of the Joint Action Plan (JAP) in 2005 (subsequently revised in 2008), which identified key areas of bilateral cooperation including peace and security, sustainable development, research and technology and educational and cultural exchanges. ${ }^{1}$

The sustained growth in relations between India and the European Union (EU) can largely be attributed to the growing levels of bilateral trade and investment between the two countries. While the EU is India's leading trade partner (bilateral trade flows were valued at nearly €86 billion in 2010), it is also India's largest source of foreign direct investment (FDI) (with a stock of €34.4 billion in the same year). ${ }^{2}$

In addition to the above, the education sector has also played an important role in connecting the two markets. A combination of factors including the large scale commercialization of the higher education industry and international labour market needs (fueled by a changing demographic structure in many Western economies) has led to the provision of education as a tradable service. A natural consequence of this has been the internationalization of higher education, a process that initially fueled and is currently sustained by the large flows of internationally mobile students. In this domain, India and the EU are key stakeholders as leading consumers and providers of education services, respectively. While this has established the scope for mutual gains, it is vital to understand the factors that fuel the mobility of international students between these markets.

Within Europe, the United Kingdom (UK) is an established player and hosts the maximum number of international students. Till date, substantial research on student mobility has examined the attractiveness of the UK market, but it is also essential to understand the factors that affect international student flows to the 'middle players', or upcoming European markets such as Germany and France. This paper attempts to address this issue and focuses on student flows to Germany and France, with the intent to identify factors that affect Indian student flows to these increasingly popular destinations of higher education in Europe.

The paper is organized as follows: Section 2 presents a historical perspective on the development of international student mobility in Europe, followed by Section 3 which provides an overview of the current distribution of internationally mobile students across Europe and a detailed distribution of Indian students who choose Germany and France. Section 4 identifies a number of reasons why Germany and France encourage (inward) non-European student mobility, followed by Section 5 which outlines features of the German/ French higher education systems which attract non-European students and Section 6 elaborates on certain challenges faced by Indian students in Germany/France (based on

\footnotetext{
${ }^{1}$ India- EU Strategic Partnership Joint Action Plan. http://commerce.nic.in/india-EU-jap.pdf (last accessed on 23.4.2012)

2 Statistics on FDI stocks is based on World Bank statistics on India. http://trade.ec.europa.eu/doclib/docs/2006/september/tradoc_113390.pdf (last accessed on 30.6.2012)

The EU is India's largest trading partner and the trade in goods and services in 2010 were approximately valued at $€ 86$ billion. http://www.consilium.europa.eu/uedocs/cms_data/docs/pressdata/EN/foraff/127832.pdf (last accessed on 29.7.2012)
} 
findings from a primary survey on Indian students in Europe). Section 7 discusses the implications of increasing competition (from emerging host countries) for Germany and France and Section 8 summarizes the main findings and concludes with policy recommendations.

\section{Student mobility in Europe}

The role of student mobility in Europe has undergone considerable change in the $21^{\text {st }}$ century. In particular, significant changes in the role of student mobility within Europe can be traced back to the period following the Second World War. In the years following the Second World War, international student mobility (within Europe) was encouraged with the intent of improving bilateral relations within Europe, which were severely damaged as a consequence of the war. Student mobility served the dual purpose of enhancing mutual understanding between countries, in addition to promoting educational and professional engagements at the international level (Teichler, 2009).

In subsequent years, the launch of the ERASMUS Programme (1987) marked one of the most significant achievements in European cooperation on higher education. Students who participated in the ERASMUS Programme were provided scholarships to study in another European country for up to one year. ${ }^{3}$ By way of promoting intra-European student mobility, staff mobility and recognition of courses amongst other objectives, the ERASMUS Programme was pivotal in enhancing educational engagements among European countries.

In the following decade, however, the European Community developed a growing interest in worldwide student mobility. A significant step in this direction was the initiation of the Bologna Process in 1999, which aimed at promoting the internationalization of higher education in Europe by establishing convergent structures of study programmes across Europe. ${ }^{4}$ Considered to be one of the most prominent policy developments in Europe, the implementation of the Bologna Process was expected to achieve the dual objective of facilitating intra-EU student mobility and improving the attractiveness of European higher education for Non-European students. It is therefore seen that certain reforms have been implemented over time to develop the European system of higher education and enhance its global appeal to non-European students. The gradual implementation of the degree structure by EU members led to the formation of the European Higher Education Area (EHEA); an ambitious goal of the EU policy makers which was finally realized in 2010, following ten years of implementation of the Bologna process. ${ }^{5}$

Statistics on international student flows reveal the positive effect of the policy initiatives (outlined above) on student flows to Europe. Trends in international student flows suggest that European countries have collectively received a growing number of non-European students in the last decade. However, national policies on higher education differ significantly across member states and consequently the European higher education market has remained "segmented into regional or national markets" (Musselin, 2004). Hence the vision of the EHEA can be completely realized only when member states are unified in their efforts. While this is likely to imply an alignment of national policies in the long run, one way of increasing the visibility of European higher education (on the global map) is to improve the attractiveness of the popular host countries in Europe.

For long, the United Kingdom (UK) has been the most internationally recognized destination in Europe and has consistently attracted the maximum number of internationally mobile students. However, since 1996, Germany and France (among other countries) have also taken keen interest in international students and consequently received a growing number of non-European students since 2000. The market features of the latter differ substantially from those of the UK (and other popular

\footnotetext{
${ }^{3}$ http://ec.europa.eu/education/erasmus/history_en.htm (last accessed on 28.4.2012)

${ }^{4}$ http://ec.europa.eu/education/policies/educ/bologna/bologna.pdf (last accessed on 28.4.2012)

${ }^{5}$ http://ec.europa.eu/education/pub/pdf/higher/ehea_en.pdf (last accessed on 30.4.2012)
} 
destinations like the US) and international students (especially non-European students) perceive these markets in a unique way. Germany and France are also important market in the context of internationalization of higher education as they have individually pursued strategies to promote student mobility from non-European countries.

Consequently, this paper identifies features of higher education in Germany and France, which have contributed to increasing international student mobility between Europe and other parts of the world. The emphasis is on analyzing the trend of Indian students choosing Germany and France as India is one of the leading source countries of all internationally mobile students. Further, not only does India host the youngest population, it is also broadly characterized by improving economic conditions and an increasing willingness to spend on higher education. As the following analysis will reveal, India is well poised to sustain and possibly increase the flow of students going abroad for higher education in the foreseeable future.

The next section presents current trends in student mobility and a detailed distribution of Indian students across Europe. The discussion is based on statistics on international student flows and other country-specific distributions, which have been sourced from the following databases:

1. UNESCO: The data used in subsequent sections have been sourced from the UNESCO database on tertiary education (ISCED levels 5 and 6). The statistics on international or internationally mobile students refers exclusively to students who have crossed national or territorial border for the purpose of higher education and are now enrolled outside their country of origin.

2. Institute of International Education (IIE): This source has been used for the list of main source countries for UK, Germany, and France.

3. Country-specific statistics on the distribution of Indian (and international) students across levels and fields of study have been sourced from the Campus France and the DAAD (German Academic Exchange Service) website.

\section{Overview of International students}

Cross-border student mobility has been on the rise since the late nineties and the development in this trend is summarized below.

UNESCO statistics on internationally mobile students reveal that the number of students seeking higher education abroad has grown steadily from 0.91 million in 1998 to over 3.1 million in 2009. In particular, international student flows registered the strongest annual growth of nearly 17 percent between 2001 and 2002. However, the annual growth in international students has slowed down since 2004 and grown at an average annual rate of 4.3 percent between 2004 and $2009{ }^{6}$

\subsection{Host Countries}

Statistics show that traditional English-speaking countries like the United States (US), United Kingdom (UK) and Australia have been the most popular destinations for international students, and continue to collectively receive over 40 percent of all mobile students. ${ }^{7}$

The US has the dominant position in the international student market and has consistently received the maximum number of all internationally mobile students, though its share has gradually declined from 27.6 percent (in 1999) to 21.2 percent (in 2009). Similarly, the UK has experienced a decline in its market share from 14.2 percent in 1999 to 11.9 percent in 2009, while Australia's share has

\footnotetext{
${ }^{6}$ Refer to Table A.1 in Annexure 1.

${ }^{7}$ Refer to Table A.2 in Annexure 1.
} 
remained at nearly 7.3 percent over the same period. The other prominent countries with a sizeable share are France and Germany, which received 8 percent and 6.4 percent of all international students in 2009, respectively. ${ }^{8}$

Despite the international student market being concentrated amongst a few host countries (identified above), recent reports suggest that countries like Canada, New Zealand and Japan have successfully entered the industry in the last three years and gained popularity in a number of source countries (this issue will be examined in detail in a subsequent section of the paper). The implication is that internationally mobile students have gradually broadened their perspective to consider unconventional and upcoming markets for higher education abroad.

The remainder of the analysis will explore the composition of international students from a European perspective.

\subsection{International students in Europe}

The European continent receives the largest share of all internationally mobile students and attracted 47.7 percent of all international students in 2009. However, similar to the overall trend, the growth in international students received by Europe has slowed down since 2004 to an average (annual) rate of 3.5 percent between 2004 and 2009. ${ }^{9}$

Within Europe, the UK, France and Germany are the most popular destinations and cumulatively attracted over 55 percent of all international students (who chose Europe) between 2000 and 2009. However, unlike the UK or France, Germany's share of international student has declined considerably from over 20 percent in 2000 to 13.3 percent in 2009. Italy and Spain are other European countries, which receive international students, followed by newer countries like Switzerland and Sweden, as seen in Figure 1, which indicates more diversification in student preferences since 2000.

Figure 1. Distribution of international students (in Europe) across main host countries (\%)

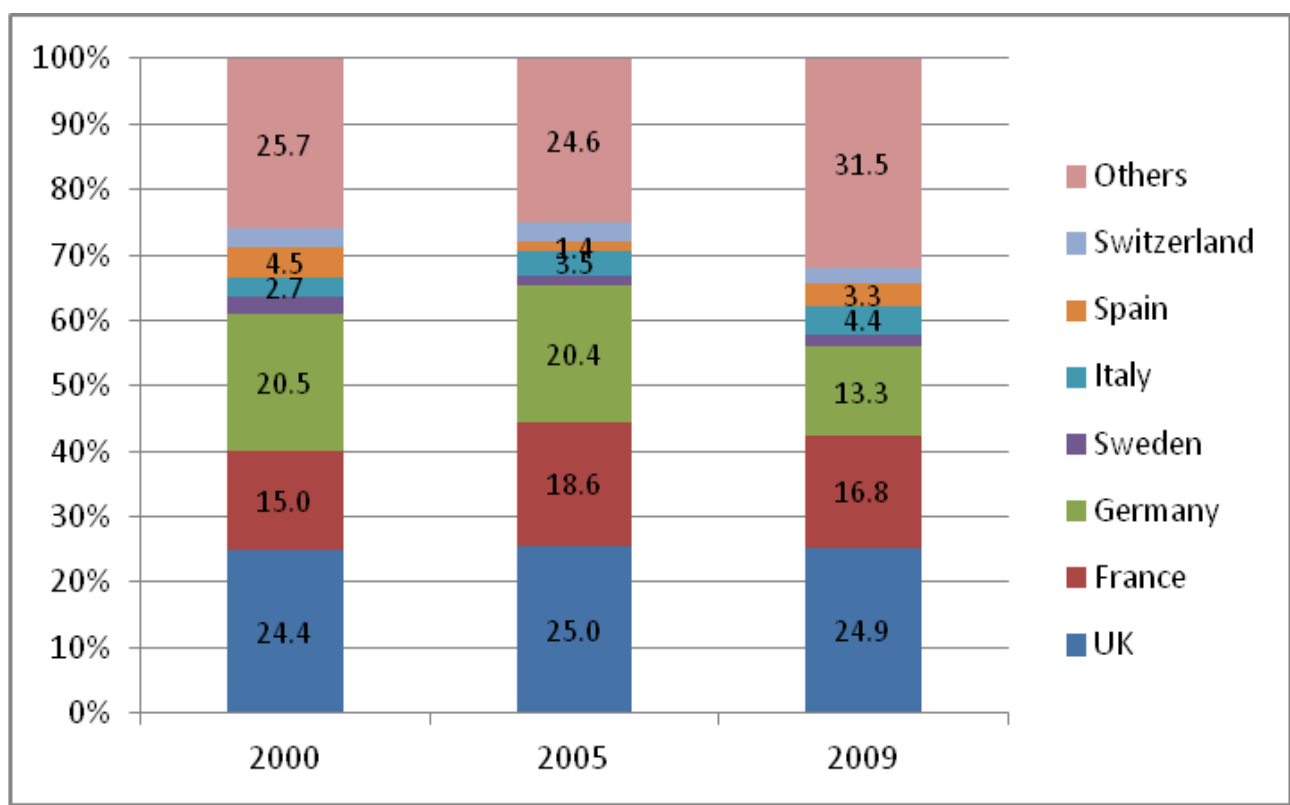

Source: Based on statistics from the UNESCO database on International students at tertiary level (ISCED 5 and 6) http://stats.uis.unesco.org/unesco/ReportFolders/ReportFolders.aspx (last accessed on 2.5.2012)

\footnotetext{
${ }^{8}$ Refer to Table A.2 in Annexure 1.

${ }^{9}$ Refer to Table A.1 in Annexure 1.
} 
It is important to note that the European share of nearly 48 percent of all international students does not represent worldwide mobility. A distribution of students across source countries reveals the predominant occurrence of regional or intra-European mobility.

As seen in Table 1, a majority of international students received by Europe come from other European countries. While such high levels of 'European' mobility partially reflect the successful implementation of European educational programmes (like the Socrates which promoted intra-European student mobility) since the early nineties, the share of European students has declined from a high of 49 percent in 2000 to 39.6 percent in 2009. Over time, more students from non-European countries have chosen Europe for higher education, with an increasing representation of Asian students.

Table 1. Regional distribution of (incoming) international students in Europe (\%)

\begin{tabular}{|l|r|r|r|}
\hline \multicolumn{1}{c|}{$\begin{array}{c}\text { Host Region } \\
\text { (Incoming international students) }\end{array}$} & $\mathbf{2 0 0 0}$ & \multicolumn{1}{c|}{$\mathbf{2 0 0 5}$} & \multicolumn{1}{c|}{$\mathbf{2 0 0 9}$} \\
\hline Africa & 15.0 & 15.1 & 13.5 \\
\hline North America, Central America and Caribbean & 4.4 & 3.8 & 3.8 \\
\hline South America & 2.7 & 2.3 & 3.4 \\
\hline Asia & 24.5 & 30.9 & 33.2 \\
\hline Europe & 48.9 & 38.3 & 39.6 \\
\hline Oceania & 0.3 & 0.3 & 0.3 \\
\hline Unspecified region and country & 2.6 & 9.3 & 5.9 \\
\hline
\end{tabular}

Source: Based on statistics from the UNESCO database on International students at tertiary level (ISCED 5 and 6 ) http://stats.uis.unesco.org/unesco/ReportFolders/ReportFolders.aspx (last accessed on 2.5.2012)

It is seen from Table 1 that the number of Asian students received by Europe has consistently increased since 2000 and represented a third of all international students (in Europe) in 2009.

Table 2. Students from Asia (as a percentage share of (total) International Students in Europe) (\%)

\begin{tabular}{|l|r|r|r|l|r|}
\hline \multicolumn{2}{|c|}{2000} & \multicolumn{2}{c|}{2005} & \multicolumn{2}{c|}{2009} \\
\hline Turkey & $3.8 \%$ & China & $8.6 \%$ & China & $8.4 \%$ \\
\hline China & $2.1 \%$ & Turkey & $2.6 \%$ & India & $3.5 \%$ \\
\hline Kazakhstan & $1.9 \%$ & India & $2.0 \%$ & Kazakhstan & $2.0 \%$ \\
\hline Iran & $1.5 \%$ & Kazakhstan & $1.9 \%$ & Turkey & $1.8 \%$ \\
\hline Malaysia & $1.2 \%$ & Cyprus & $1.5 \%$ & Malaysia & $1.3 \%$ \\
\hline Japan & $1.2 \%$ & Malaysia & $1.2 \%$ & Pakistan & $1.2 \%$ \\
\hline Israel & $1.1 \%$ & Iran, Islamic Rep & $1.0 \%$ & Iran & $1.1 \%$ \\
\hline Korea & $1.1 \%$ & Korea & $0.9 \%$ & Viet Nam & $1.1 \%$ \\
\hline Hong Kong (China) & $0.9 \%$ & Japan & $0.9 \%$ & Korea & $0.9 \%$ \\
\hline Cyprus & $0.8 \%$ & Hong Kong (China) & $0.8 \%$ & Cyprus & $0.8 \%$ \\
\hline Others & $8.9 \%$ & Others & $9.4 \%$ & Others & $11.2 \%$ \\
\hline $\begin{array}{l}\text { Students from Asia (as a share of } \\
\text { international students in Europe) }\end{array}$ & $24.5 \%$ & & & & \\
& & & $30.9 \%$ & & $33.2 \%$ \\
\hline
\end{tabular}

Source: Based on statistics from the UNESCO database on International students at tertiary level (ISCED 5 and 6) http://stats.uis.unesco.org/unesco/ReportFolders/ReportFolders.aspx (last accessed on 2.5.2012) 
China is the most represented country amongst all Asian students received by Europe. There has been significant growth in the flow of Chinese students, as their share rose from a mere 2.1 percent in 2000 to over 8 percent by 2009 .

An equally important feature is the steady growth registered by Indian students. Up until 2000, Indian students constituted less than 1 percent of all international students in Europe. However, their share has consistently risen since then and India became second-largest sending country (from Asia) in 2009.

\subsection{Internationally mobile Indian Students}

Overall, India sources the largest number of internationally mobile students after China. Student flows from India have increased substantially since 2000 and grew by over 256 percent (from 53,266 to 190781) between 2000 and 2009. In 2009, Indian students constituted 6.2 percent of all international students. ${ }^{10}$

The presence of Indian students in Europe has also increased during the period, as indicated by Europe's share of (internationally mobile) Indian students which has increased from 12.7 percent in 2000 to 27 percent by 2009.

Table 3. Indian students in Europe

\begin{tabular}{|l|r|r|r|}
\hline & Indian Students (World) & Indian students in Europe & Share of Europe (\%) \\
\hline $\mathbf{2 0 0 0}$ & 53266 & 6772 & $12.7 \%$ \\
\hline $\mathbf{2 0 0 1}$ & 58683 & 7585 & $12.9 \%$ \\
\hline $\mathbf{2 0 0 2}$ & 91189 & 10327 & $11.3 \%$ \\
\hline $\mathbf{2 0 0 3}$ & 110716 & 17227 & $15.6 \%$ \\
\hline $\mathbf{2 0 0 4}$ & 125881 & 22345 & $17.8 \%$ \\
\hline $\mathbf{2 0 0 5}$ & 138072 & 25962 & $18.8 \%$ \\
\hline $\mathbf{2 0 0 6}$ & 136238 & 28496 & $20.9 \%$ \\
\hline $\mathbf{2 0 0 7}$ & 154116 & 34084 & $22.1 \%$ \\
\hline $\mathbf{2 0 0 8}$ & 176454 & 41735 & $23.7 \%$ \\
\hline $\mathbf{2 0 0 9}$ & 190781 & 51566 & $27.0 \%$ \\
\hline
\end{tabular}

Source: Based on statistics from the UNESCO database on International students at tertiary level (ISCED 5 and 6 ) http://stats.uis.unesco.org/unesco/ReportFolders/ReportFolders.aspx (last accessed on 2.5.2012)

Internationally mobile Indian students are particularly concentrated in English-speaking host countries like the US, the UK, and Australia. The US has been the leading host country for Indian students and received over 53 percent of all Indian students in 2009. Together with the UK and Australia, the English-speaking countries hosted over 80 percent of all Indian students. ${ }^{11}$

Though (Indian) student preferences are considerably skewed in favour of English-speaking destinations, there has been a growing interest in countries like Germany and France. Though their share of Indian students remained relatively low in 2009 (1.7 percent and 0.7 percent, respectively), annual flows have been on the rise. ${ }^{12}$

\footnotetext{
${ }^{10}$ Refer to Table A.3 in Annexure 1.

11 Refer to Table A.4 in Annexure 1.

${ }^{12}$ Refer to Table A.4 in Annexure 1.
} 
Within Europe, Indian students are heavily concentrated in the UK, which received over two thirds of all Indian students in 2009, followed by Germany and France which received 6.3 percent and 2.4 percent respectively, in the same year. In addition to the UK, Germany and France are therefore more likely to receive students from India.

Figure 2. Distribution of Indian students (as a percentage share of total Indian students in Europe)

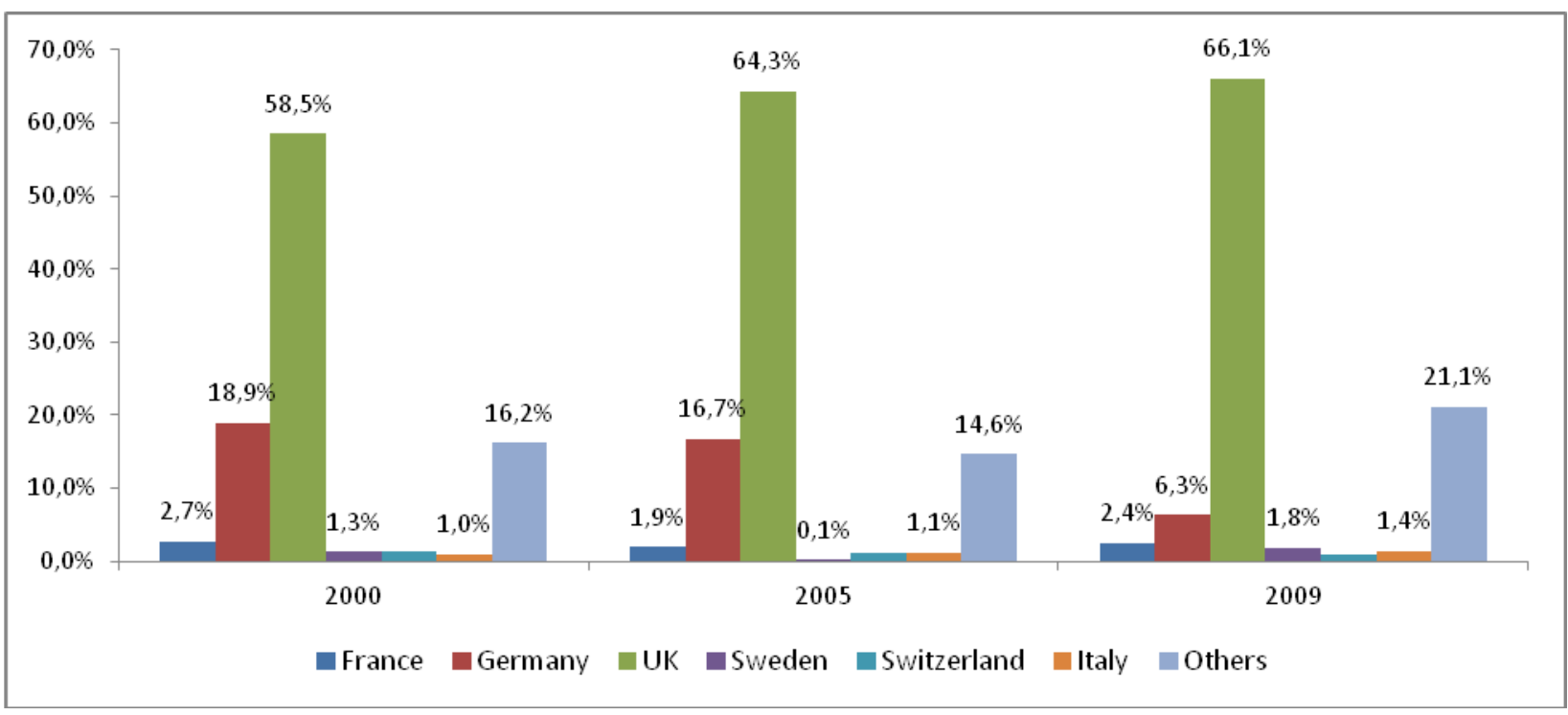

Source: Based on statistics from the UNESCO database on International students at tertiary level (ISCED 5 and 6) http://stats.uis.unesco.org/unesco/ReportFolders/ReportFolders.aspx (last accessed on 2.5.2012)

\subsubsection{Indian students in Germany}

Being one of the world's leading research-oriented countries, Germany has always received foreign students in large numbers, who constituted nearly 12.4 percent of all students in Germany in 2010-11. China, Turkey, and Russia are the main sending countries of international students in Germany and cumulatively sourced nearly 30 percent of all international students in 2009-10. ${ }^{13}$

India currently ranks 14th on the list of top sending countries and Indian students constitute nearly 2 percent of all international students in Germany. As seen in Figure 3, the flow of Indian students to Germany has fluctuated between 1997 and 2011. While the number of Indian students studying in Germany steadily increased from 1117 to 4249 (by 280 percent) between 1999 and 2004, the numbers reduced to 3516 (or by 17.3 percent) between 2004 and 2008. However, the period since then indicates a strong revival in the trend, as the enrollments grew by a remarkable 43.3 percent between 2008 and 2010 .

\footnotetext{
${ }^{13}$ For the list of top ten source countries for Germany, refer to Table A.5 in Annexure 1. http://www.iie.org/Services/ProjectAtlas/Germany/International-Students-In-Germany
} 
Figure 3. Indian Students in Germany
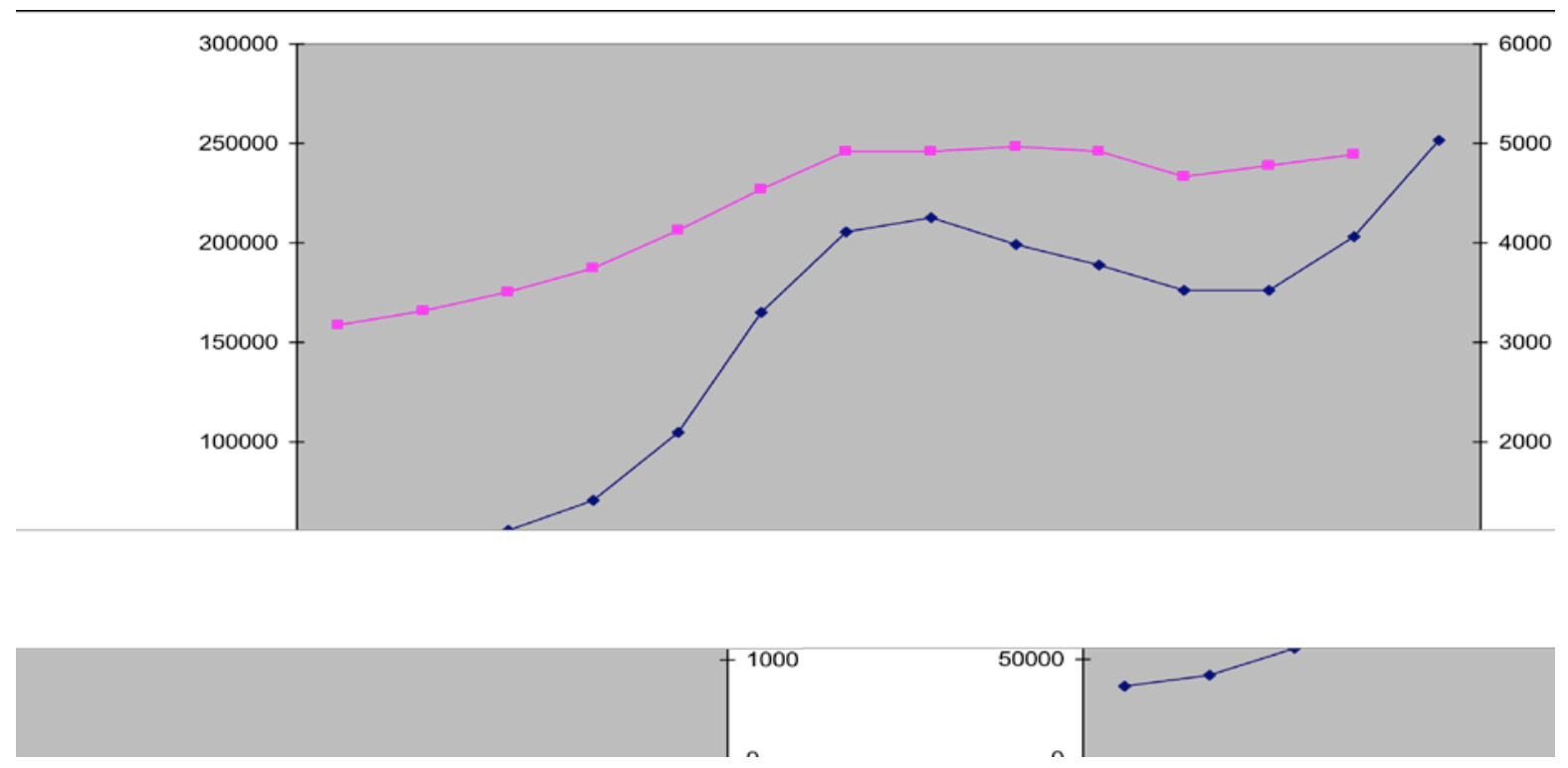

Source: Federal Statistical Office, Germany, www.eds-destatis.de/en_index.php (last accessed on 30.10.2011)

The distribution of Indian students in Germany is highly skewed as only 10 percent of all Indian students enroll in under graduate courses while the majority opt for post graduate and doctorate degrees, as seen in Table 4. The Table also highlights that there has been a shift in favour of doctoral studies as the share of Indian students under this level increased from 21.5 percent to over 30 percent between 2004-05 and 2009-10.

Table 4. Breakdown of Indian students in Germany by level of study

\begin{tabular}{|l|r|r|}
\hline Level of Study/Year & 2004-05 & \multicolumn{1}{|l|}{ 2009-10 } \\
\hline $\begin{array}{l}\text { Overall, before } \\
\text { Master's degrees }\end{array}$ & $15.2 \%$ & $10.3 \%$ \\
\hline $\begin{array}{l}\text { Undergraduate degrees } \\
\text { including Masters }\end{array}$ & $58.2 \%$ & $56.9 \%$ \\
\hline Doctoral Studies & $21.5 \%$ & $30.5 \%$ \\
\hline $\begin{array}{l}\text { Not studying for a } \\
\text { degree }\end{array}$ & $5.0 \%$ & $2.3 \%$ \\
\hline
\end{tabular}

Source: Federal Statistical Office, Germany, www.edsdestatis.de/en_index.php (last accessed on 30.10.2011)

A number of Indian students in Germany tend to specialize in areas of Engineering (Mechanical and Process Engineering), Information Technology (IT), Sciences (Biology and Chemistry) and Economics, as seen in Table 5. The distribution of Indian students across subjects also illustrates that, contrary to the popular belief, very few Indian students in Germany join art, culture and social science related courses. 
Table 5. Breakdown of Indian students in Germany by subject area (\%)

\begin{tabular}{|l|r|c|}
\hline Subject Area & $\mathbf{2 0 0 4 - 0 5}$ & $\mathbf{2 0 0 9 - 1 0}$ \\
\hline Electrotechnology & 20.9 & 12.6 \\
\hline Biology & 7.5 & 11.8 \\
\hline Mechanical and Process Engineering & 16.5 & 11.5 \\
\hline Information Technology & 12.1 & 10.8 \\
\hline Economics & 4.7 & 10.3 \\
\hline Chemistry & 9.2 & 8.0 \\
\hline Physics, Astronomy & 4.0 & 4.0 \\
\hline Traffic Engineering, Nautical Science & 0.9 & 4.0 \\
\hline Human Medicine & 2.4 & 3.5 \\
\hline Engineering in general & 4.5 & 3.1 \\
\hline Mathematics, Natural Sciences in general & 1.1 & 2.3 \\
\hline Others & 16.2 & 18.1 \\
\hline
\end{tabular}

Source: Federal Statistical Office, Germany. www.eds-destatis.de/en_index.php (last accessed on 30.10.2011)

Indian students therefore constitute 2 percent of the international student population in Germany (2010-11) and a majority of them pursue postgraduate or doctorate courses in the preferred fields of engineering, Sciences (Biology and Chemistry), IT and Economics.

\subsubsection{Indian students in France}

Nearly 8 percent of all internationally mobile students have chosen France as a destination for higher education since 2000. Though its share of (total) international enrolments has remained relatively unchanged, the number of international students in France has increased by 81.7 percent since $2000 .{ }^{14}$

Morocco, China, Algeria and Tunisia are the main countries of origin for international students and cumulatively sourced over 34 percent of all international students in France in 2009-10. ${ }^{15}$

The number of Indian students in France has remained comparatively low, as India ranked $15^{\text {th }}$ in the list of top sending countries to France. Though the enrollments have increased from 185 in 2000 to 1252 in 2009, their share in international students has remained under 1 percent until 2009.

\footnotetext{
${ }^{14}$ Refer to Table A.6 in Annexure 1.

${ }^{15}$ For the distribution of international student shares in France, refer to Table A.7 in Annexure 1. http://www.iie.org/Services/Project-Atlas/France/International-Students-In-France
} 
Figure 4. Indian students in France

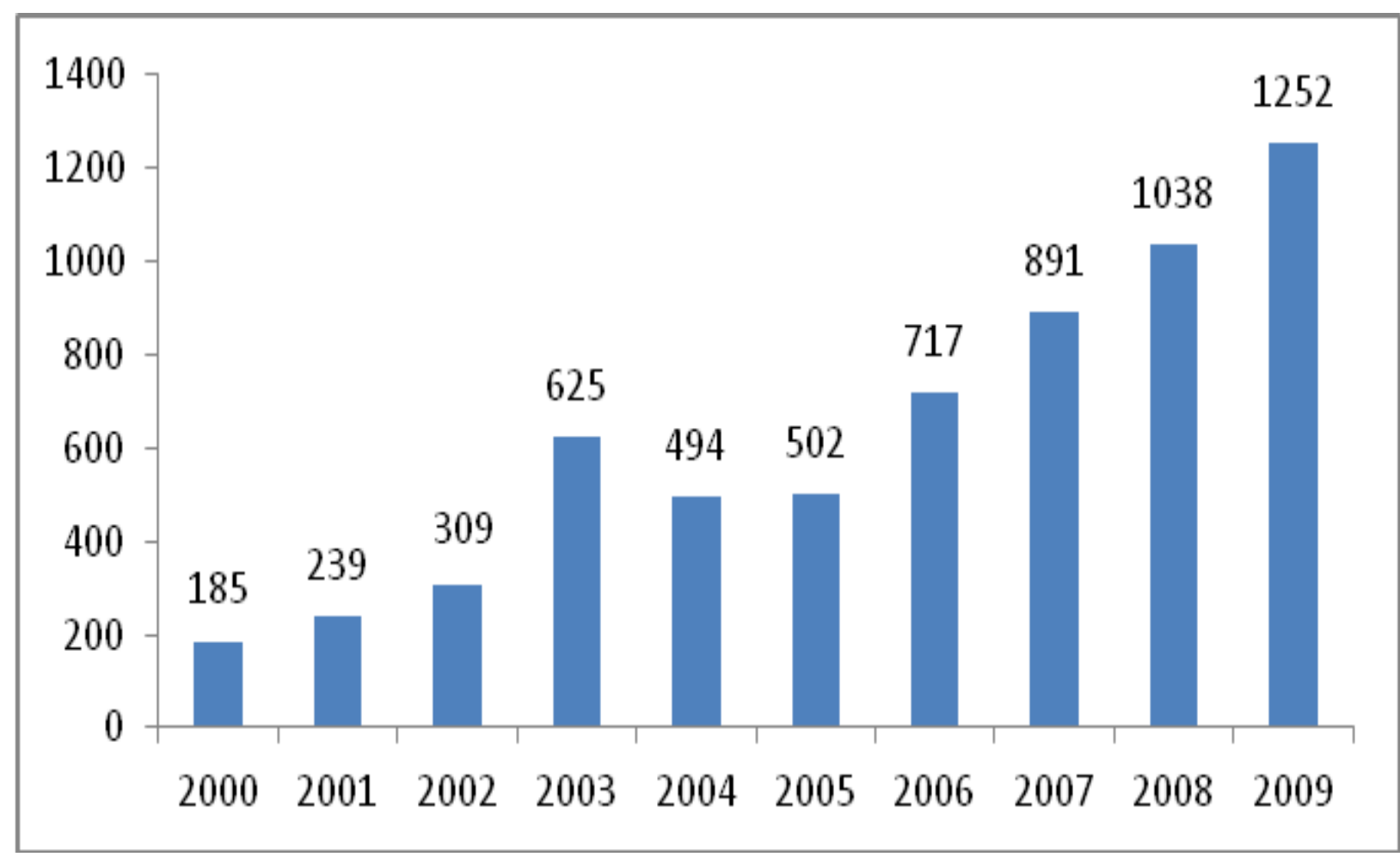

Source: UNESCO database on International students at tertiary level (ISCED 5 and 6)

http://stats.uis.unesco.org/unesco/ReportFolders/ReportFolders.aspx (last accessed on 2.11.2011)

A distribution of Indian students across levels of study in France suggests that there has been a significant shift in favour of doctorate level studies since 2005, as seen in Figure 5. Similar to Indian students in Germany, there has been a decline in the strength of undergraduate students from India.

Figure 5. Distribution of Indian students in France by level of study (\%)

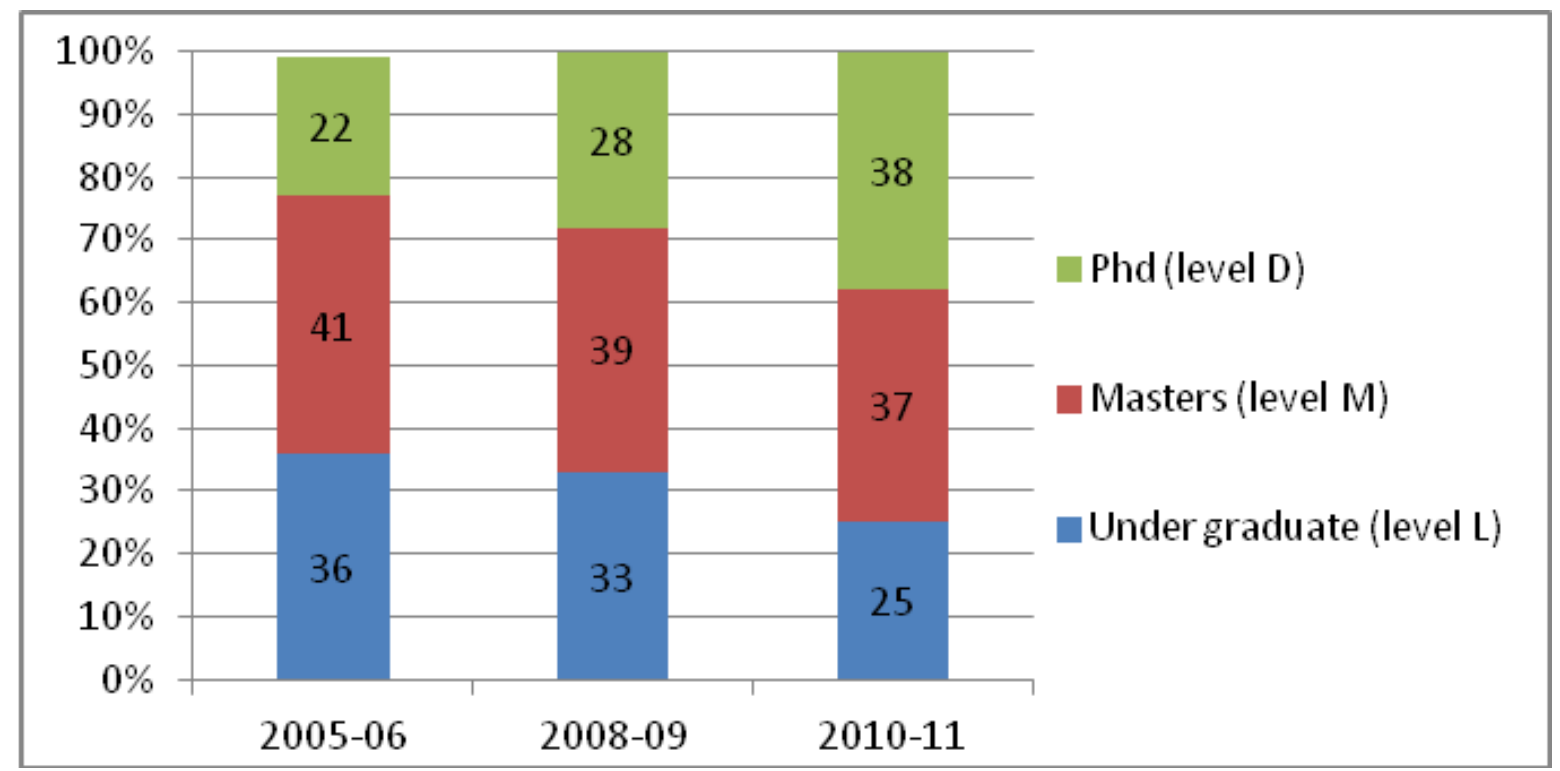

Source: International Mobility Records- Campus France: India

http://www.campusFrance.org/fr/ressource/les-dossiers-pays-campusFrance-inde (last accessed on 4.11.2011) 
A subject-wise distribution suggests that Indian students are concentrated in the fields of science and humanities, which account for almost 70 percent of all Indian students followed by Economics, as seen in Figure 6. In recent years, a number of Indian students also opt for niche areas like helicopter and aerospace engineering and wine management. ${ }^{16}$ Moreover, nearly 89 percent (260 out of 294) of all Indian doctorate students were specializing in science in the academic year 2010-11. ${ }^{17}$

Figure 6. Breakdown of Indian students in France by discipline in 2008-09

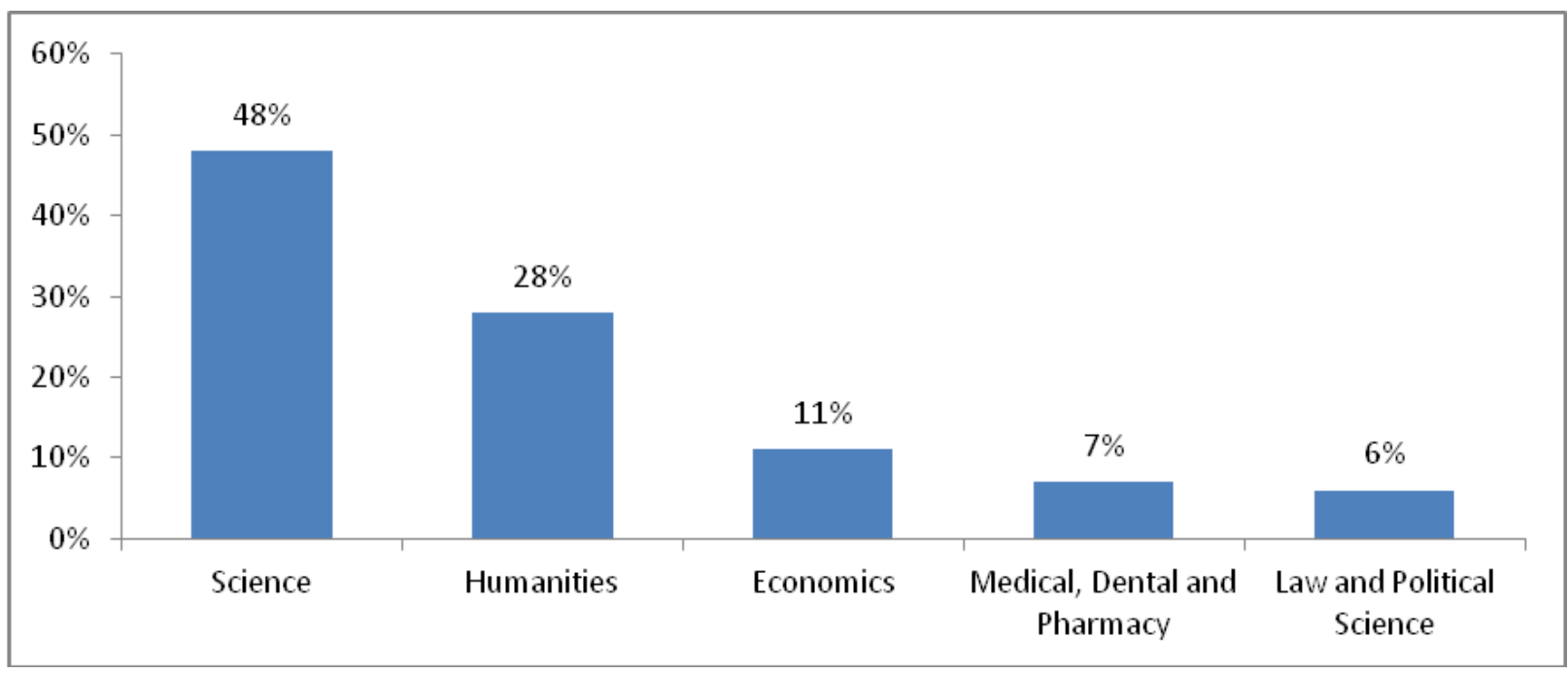

Source: International Mobility Records- Campus France: India

http://www.campusFrance.org/fr/ressource/les-dossiers-pays-campusFrance-inde (last accessed on 4.11.2011)

Overall, Indian students constitute a small share of 0.5 percent of international students in France (as of 2009) and a majority of them pursue post graduate and doctorate degrees in the fields of Science, Humanities and Economics.

\section{Motivations driving the Demand for International students in Germany and France}

A number of developments have shaped the flow of Indian students going to Germany and France for higher education. The following discussion identifies a few changes that have facilitated this process.

The growing interest in student mobility from non-European countries can be attributed to a change in the European or regional perspective of higher education since the late nineties (Marginson, 2006). However, the educational policies implemented were country-specific, which granted each nation a certain degree of autonomy. As a consequence of this, most European countries were seen to promote international or non-European student mobility with varying intensity.

Germany and France shared a common interest in promoting student mobility as they were among the signatories of the Sorbonne declaration in 1998 (which preceded the Bologna declaration), which called for changes in the existing higher education systems to "enhance mobility" ${ }^{18}$ In subsequent years, a number of changes have been introduced by both countries to improve their attractiveness. However, it is also necessary to understand why international students are important to these markets. What are the motivations behind promoting higher education abroad?

\footnotetext{
${ }^{16}$ As per an interview with a representative from Campus France, India (New Delhi).

${ }^{17}$ The share of (Indian) $\mathrm{PhD}$ students within the science stream is 56 percent and the highest amongst all streams in France.

${ }^{18}$ http://www.accreditation.org/accords.php?page=SorbonneDeclaration (last accessed on 2.5.2012)
} 
Overall, there is a consensus among Germany, France and other Western economies that internationalization (in the form of international student mobility) tends to improve the educational quality of the respective systems. ${ }^{19}$ International students are also seen to positively contribute to the development of knowledge-intensive economies, which is also one of the chief objectives of the European Higher Education Area (EHEA). However, there also exists significant differences in the way Germany and France perceive the role of international students.

Germany targets multiple objectives by attracting more international students. One of the major challenges facing the German economy is a diminishing demographic trend. While birth rates in western European economies have remained low, the fertility rate was the lowest in Germany at 1.42 (children per mother) and below the replacement rate of 2.1 (2009-10 estimate) ${ }^{20}$ Combined with the problem of an ageing workforce, Germany may well face a shortfall of nearly 5 million workers in the next fifteen years. ${ }^{21}$ Under these circumstances, the presence of international students may be beneficial for Germany in addressing its labour market requirements in the long run.

"Winning over foreign students is how we will make friends and partners for the future. What is more, if we fail to increase the number of international students in Germany, we will be unable to maintain our academic system’s excellence in light of demographic changes."

Prof. Margaret Wintermantel (DAAD President) ${ }^{22}$

According to a senior representative of DAAD, promoting international student mobility, though important, forms a part of a much larger objective. Since 2000, Germany has made significant efforts to 'internationalize' every dimension of higher education. Therefore, in addition to promoting student mobility (inbound and outbound), policies at the national and institutional level have increasingly emphasized on promoting academic staff mobility and international research collaborations.

France views international student mobility as a means of improving the overall quality of education and thereby, its international competitiveness. According to a representative of Campus France in India, the quality dimension is of prime importance to the French education system, and emphasis is not necessarily on increasing student flows, but rather on attracting the "best talent" from all parts of the world. Additionally, promoting (inward) student recruitment is also a means to enhance diplomatic or political relations. ${ }^{23}$ Thus, receiving international students also presents another platform for cooperation between France and its strategic partners.

From a student perspective, a number of factors motivate Indian students to seek higher education abroad. Very few universities and engineering institutes in India are known to disseminate quality education, and this shortage results in excessive competition amongst aspiring students. An example of this is the much sought after Delhi University, which has consistently raised its cutoffs (for admission into undergraduate courses), which usually range between 90 and 95 percent for popular subjects like Economics. The competition is equally intense in the field of Engineering, where over 500,000 students compete for merely 9,600 seats offered by the reputed Indian Institutes of Technology (IITs) ${ }^{24}$ In its present state therefore, the Indian education sector lacks the infrastructure required to cope with the growing demand for (postgraduate and doctorate) courses in Sciences,

\footnotetext{
${ }^{19}$ For more information, see the NUFFIC Report titled, 'Competing for the brightest minds'. http://www.nuffic.nl/en/news/latest-news/competing-for-the-brightest-minds (last accessed on 3.5.2012)

${ }^{20}$ http://www.forbes.com/forbes/2012/0507/current-events-population-global-declining-birth-rates-lee-kuan-yew.html (200910 estimate) (last accessed on 2.5.2012)

${ }^{21}$ http://www.guardian.co.uk/world/2011/mar/17/new-europe-germany-retirement-pensions-exports (last accessed on 2.5.2012)

22 http://daadndnews.org/daad/newsletter/46

${ }^{23}$ NUFFIC Report (2011) on International Student Mobility titled, “Competing for the brightest minds”. http://www.nuffic.nl/en/news/latest-news/competing-for-the-brightest-minds (last accessed on 3.5.2012)

${ }^{24}$ http://www.dnaindia.com/academy/report_5-3-lakh-aspirants-vie-for-9600-iit-seats_1501963(last accessed on 4.5.2012)
} 
Engineering and Business Management. ${ }^{25}$ Under these circumstances, the option of pursuing higher education abroad offers an attractive combination of realistic expectations, internationally recognized standards of education and importantly, a chance to compete in the global labour market. In combination with rising income levels of middle-class families, the factors stated above have led to a steady rise in internationally mobile Indian students.

In Europe, Germany and France have received the largest share of Indian students after the UK and continuing this trend in the future will be crucial for a number of reasons. For one, it is widely accepted that India sources talented students and their presence raises the overall performance standards of universities. ${ }^{26}$ Further, as a majority of Indian students specialize in areas of engineering, and Information Technology (IT), they are particularly valuable for Germany and France, which conduct extensive research in similar domains. Hosting Indian students also has financial implications, as they are known to spend nearly $\$ 13$ billion on studying abroad, which sources substantial financial resources into host economies. ${ }^{27}$

According to a senior representative of the German Academic Exchange Service (DAAD), Germany has multiple reasons for tapping the Indian market. In the short run, it seeks to attract quality students from India who add value to the existing pool of academic resources in Germany. Many Indian students are also considered valuable as they prove to be good workers. In the long run, students from various cultural backgrounds including India contribute to the diversity in the student and research base, which creates a more cosmopolitan environment for research-oriented activities. Another long-term objective of Germany is to promote bilateral exchange of staff mobility and enhance research collaborations between Indian and German universities.

According to a Campus France representative, France has similar interest in Indian students. They are seen to be good performers who add to the research capacities of French universities. France is particularly keen on Indian students in the field of IT, as they are believed to have sound understanding of various aspects of Technology. Moreover, the fact that India and France share a rich cultural legacy offers an additional point of interaction and interest between the two countries. According to another representative, promoting educational mobility is part of a larger French objective of enhancing economic and political relations between India and France.

Occasionally labeled as the "middle players", these destinations offer an attractive set of incentives, which have contributed towards building a positive image of Europe in the Indian student market. ${ }^{28}$ The following discussion elaborates on certain market features of the German and French higher education systems.

\section{Factors fueling the demand for Higher Education in Germany and France}

In recent years, a number of factors have improved the attractiveness of France and Germany as higher education destinations within Europe, and some of these are identified below.

\subsection{Reduced preference for traditional markets (United States, United Kingdom and Australia)}

Indian students for long remained concentrated in markets like the US, the UK and Australia, which were also (until recently), the leading service providers of international higher education. However, their preference has diversified in the last five years to include European countries like Germany and

\footnotetext{
${ }^{25}$ http://www.pwc.com/en_IN/in/assets/pdfs/industries/education/PwCEducationServices.pdf (last accessed on 4.5.2012)

${ }^{26}$ http://www.universityworldnews.com/article.php?story=20111209195503978 (last accessed on 4.5.2012)

${ }^{27}$ http://www.universityworldnews.com/article.php?story=20080403160850431 (last accessed on 4.5.2012)

${ }^{28}$ See Hawthorne (2008)
} 
France. Though a rise in the flow of Indian students to these countries can be partially attributed to strategic policies designed to attract them, unexpected changes in the UK and Australia have also aided the flow of Indian students to alternative destinations.

A series of racial attacks on Indians in Australia, followed by a "clampdown by the Australian government on dubious institutions" in 2009 severely damaged the Australian reputation and dampened the flow of Indian students, which dropped by a remarkable 77 percent in $2010 .^{29}$ There was also a sharp decline in Indian students going to the UK (by nearly 10 percent) in 2011, which was largely a consequence of similar racist attacks on Indians and stringent visa regulations, which discontinued the two-year Post-Study Work (PSW) scheme. ${ }^{30}$ Under the current policy, foreign students who graduate from UK universities can continue to stay in the UK provided they hold a "highly skilled job offer".

The events stated above had a visible effect on the decision of many prospective students. It is well known that Indian students incur significant financial liabilities for pursuing higher education in the UK or Australia. Due to limited availability of scholarships available for foreign students, a majority of Indian students are entirely self-financed and many of them crucially rely on securing employment in the host country on completion of studies (which is necessary for recovering the costs incurred in financing their education). The attempt to separate the 'international student' route from the migration route has affected the future prospects of several Indian students in the UK by increasing the uncertainty of finding employment and subsequently the means of repaying their financial obligation. The reduced scope of employment has therefore increased the opportunity cost associated with pursuing higher education in the UK.

The US reputation has also been affected due to incidents involving fraudulent universities coming to light in early 2011. The immigration fraud by the Tri Valley University in California was unraveled in 2011 and resulted in hundreds of Indian students being deported. This incident revealed the lack of a "single accrediting body" in the US and made a number of Indian students as well as employers more cautious about the lesser-known universities in the US. An immigration fraud of this magnitude raised serious questions about the reliability of American institutions and has consequently affected the reputation of the otherwise popular destination for Indians. Additionally, with the economic slowdown in the US economy dampening employment prospects, the overall expectations from the US may have fallen in recent times. ${ }^{31}$

A change in the perception of these popular destinations among Indian students is reflected in the results of a recently conducted survey on Indian students in Europe. ${ }^{32}$ The survey was conducted between October and December (2011) and covered nearly 120 Indian students studying in five European countries, namely, the UK, Germany, France, Italy and Spain. Of the 120 students covered, nearly 47 percent of all students were either based in Germany or in France. The results from the survey indicate that nearly 40 percent of all respondents in Germany did not consider the UK to be suitable for higher studies, while 30 percent of the respondents in France shared this opinion. In general perception about Australia was also unfavourable, as approximately 40 percent of the respondents in Germany and 35 percent of the respondents in France believed that Australia was not suitable for higher studies.

\footnotetext{
${ }^{29}$ http://articles.economictimes.indiatimes.com/2011-05-01/news/29491210_1_indian-students-uk-visa-rules(last accessed on 5.5.2012)

${ }^{30}$ This scheme had previously allowed non-EU students to stay for up to two years in the UK to find suitable employment. http://www.universityworldnews.com/article.php?story=20111209195503978 (last accessed on 5.5.2012)

31 http://www.universityworldnews.com/article.php?story=20111209195503978 (last accessed on 10.5.2012).

32 The survey on Indian students has been conducted as part of a study on Indian student mobility to European countries. A summary of the results pertaining to students in Germany and France can be found in Table A.8 of Annexure 1. For a comprehensive summary of the survey results, refer to an earlier paper on Indian student mobility to Europe. http://www.india-eu-migration.eu/media/CARIM-India\%202012\%20-\%2012.pdf
} 
The instances cited above reveal the sensitivity of Indian student flows to issues involving social security, regulations and employment opportunities. Multiple occurrences that affect their sense of safety and future opportunities may encourage more Indian students to broaden their outlook and seek out other destinations, and this is likely to result in more students considering countries such as Germany and France.

\subsection{English-Taught Programmes}

An important development in the German and French higher education systems has been a phenomenal increase in the number of programmes taught in English. A recent study conducted by the International Institute of Education (IIE) on English-taught programmes in Europe has explored this development in European higher education and some results are presented below. ${ }^{33}$

Following the reforms to implement the three-tier structure (as part of the Bologna Process) in European education systems, there has been a tremendous growth in the number of programmes offered by European universities in English (White, 2012). This overall figure has grown consistently from 1615 in 2008 to 4644 in 2011.

Germany offers the second-highest number of English-taught programmes in continental Europe (after Netherlands) amounting to 632 in 2011. France too, has a growing number of Masters Programmes taught in English, which stood at 346 in 2011. A distribution across institutional participation revealed that while 144 institutions in Germany offered 632 courses in English, as many as 102 French institutes offered an aggregate of 346 English-taught programmes in $2011 .^{34}$ It is worth noting that there was a remarkable growth in English-taught programmes particularly between 2008 and 2010, when the number increased from 170 in Germany and 31 in France (in 2008), to 522 and 260, respectively, by $2010 .{ }^{35}$ Further, a majority of all English-taught programmes (nearly 80 percent) in Germany are two-year courses. In case of France, however, such programmes are equally distributed across one-year and two-year masters courses.

The findings from the study also reveal that France as well as Germany place greater emphasis on certain areas of specialization. A common trend observed in both countries is that the English-taught programmes tend to be heavily concentrated in the areas of Business, Economics and Engineering. In case of Germany, over 35 percent of all such programmes are offered in the field of Business and Economics, followed by over 20 percent which are offered in the area of Engineering. The concentration of these programmes is stronger in France, where nearly half (48 percent) of all programmes taught in English are offered for Business and Economics, and another 28 percent are offered under engineering and technology courses.

It is worth noting that a large number of prospective students are aware of the current scenario, as the website recorded over 11 million unique viewers in 2011 and an aggregate of 26 million since its launch in 2007. Importantly, several Indian and other Asian students access this information, as nearly 25 percent of all visitors are from Asia, and 6.5 percent of all viewers are students from India. ${ }^{36}$

33 The study is based on data on online searches/queries listed on www.mastersportal.eu, a website which provides information related to higher studies in Europe. For more information on the study, see the Institute of International Education (IIE) report titled, "English-taught programmes in Europe: New findings on Supply and Demand". www.iie.org/Research.../English-Language-Masters-Final.ashx (last accessed on 10.5.2012)

${ }^{34}$ For a detailed distribution across other European countries, refer to Figure A.1 In Annexure 1.

${ }^{35}$ It is important to note that the absolute change in programmes between 2008 and 2010 (reported above) need not represent an equal rise over the period. As the results of the study are based on statistics from a website (www.mastersportal.eu), it is likely that many institutes registered (in this website), long after the introduction of English-taught programmes. For more information on this, one may refer to the study.

${ }^{36}$ For more information, see the Institute of International Education (IIE) report titled, "English-taught programmes in Europe: New findings on Supply and Demand”. 


\section{Figure 7. Website Searches for English-taught Programmes by Discipline Breakdown by Country ${ }^{37}$}

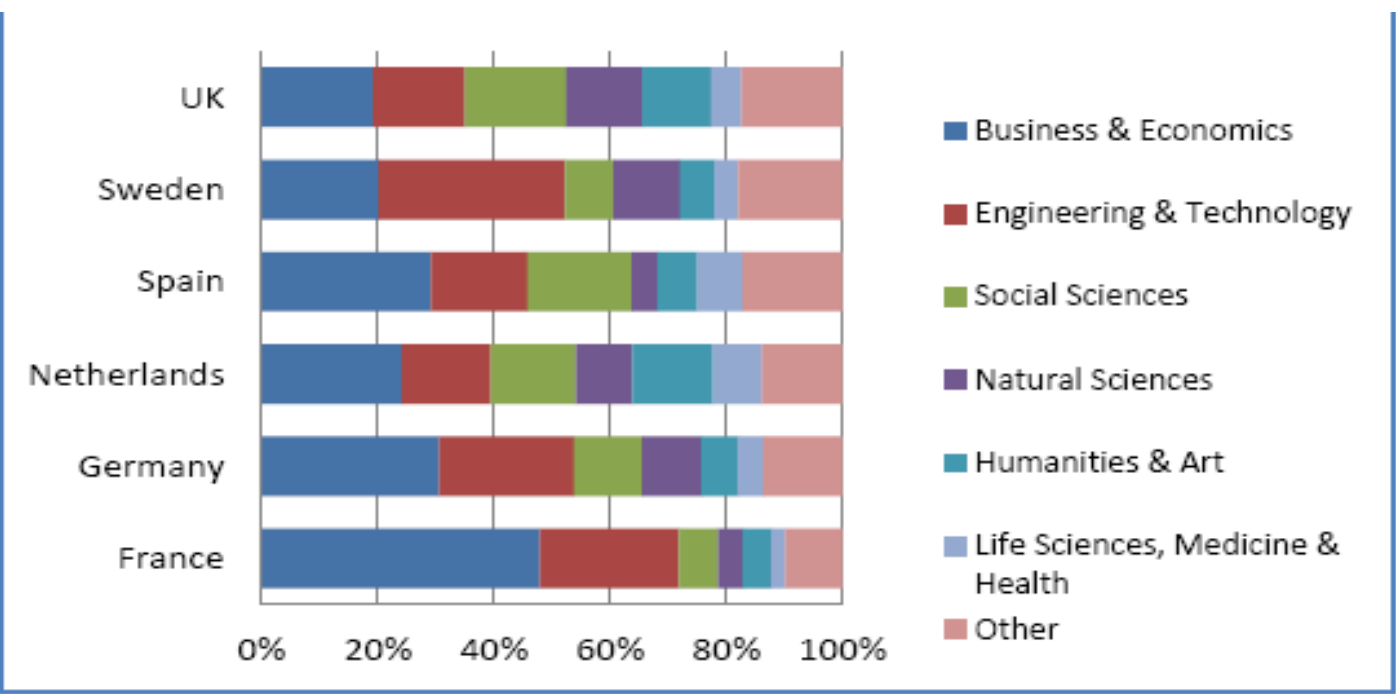

Source: Reproduced from an Institute of International Education (IIE) report titled, "English-taught programmes in Europe: New findings on Supply and Demand”. www.iie.org/Research.../English-Language-Masters-Final.ashx

(This Figure corresponds to Table 8 of the document, titled “Discipline breakdown by country”).

Note: The distribution exclusively refers to online searches in the website www.mastersprotal.eu.

\# The information presented in the Figure should be interpreted as follows: nearly 50 percent of all searches in the website for English-taught programmes in France are for courses related to Business \& Economics.

As Business, Economics and Engineering also attract the largest number of international students; the trend outlined above suggests that Germany and France are trying to improve their attractiveness by offering popular courses in English. For Indian students, the increased availability of popular courses (taught in English) in newer, yet international markets reduces the pressure of learning a foreign language and also the perceived differences between European markets like Germany or France, and conventional (English-speaking) markets like the US or the UK.

With nearly 700,000 visitors from India accessing this information, the large-scale implementation of English-taught programmes has evidently drawn the attention of Indian students to Europe for higher education. ${ }^{38}$ Further, 46 percent of all their searches are related to Engineering and Technology related courses, and 19 percent for Business and Economics courses, which are also courses that Indian students most frequently opt for.

Though the numbers presented by the study require further analysis, the initial findings imply that there is indeed a growing interest and greater awareness of English-taught programmes among several Indian students, who are actively exploring their options of higher education in Europe. Thus, a substantial rise in the number of English-taught programmes is likely to be one of the factors, which has attracted Indian students to Europe in recent years.

(Contd.)

www.iie.org/Research.../English-Language-Masters-Final.ashx (last accessed on 10.5.2012)

37 The distribution of English-taught programmes by country (and discipline) is based on searches on www.mastersportal.eu, a website which provides information related to higher studies in Europe. For more information on the study, see the Institute of International Education (IIE) report titled, "English-taught programmes in Europe: New findings on Supply and Demand”. www.iie.org/Research.../English-Language-Masters-Final.ashx (last accessed on 10.5.2012)

38 The number of visitors from India refers to the period between 2010 (September) to 2011 (August) and is an approximate figure, calculated based on the statistics provided in the report (which state that 6.5 percent of all unique viewers were from India, in a year which recorded nearly 11 million unique visitors in aggregate). 


\section{Figure 8. European Visitors by Country of Origin and Discipline (searched for)}

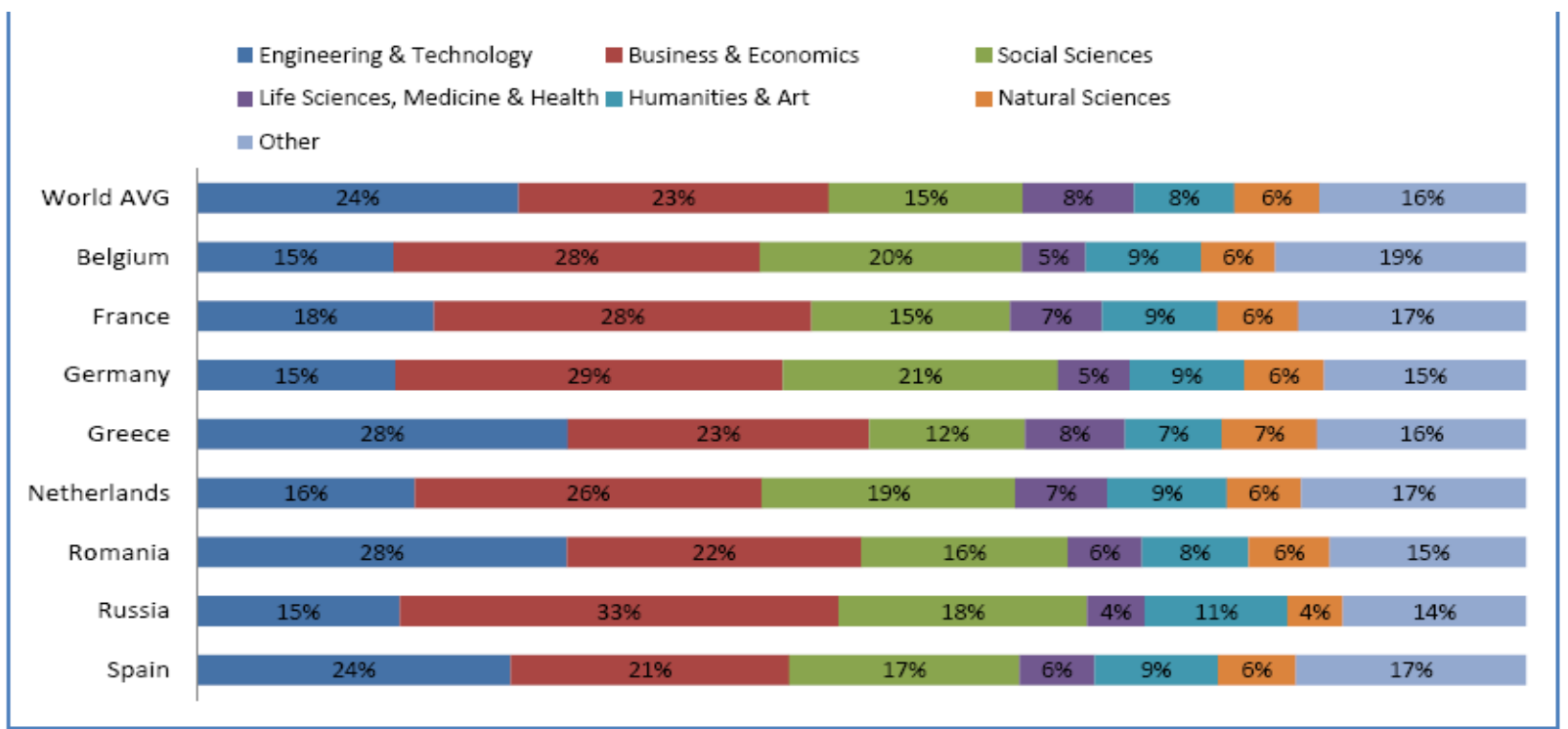

Source: Reproduced from an Institute of International Education (IIE) report titled, "English-taught programmes in Europe: New findings on Supply and Demand”. www.iie.org/Research.../English-Language-Masters-Final.ashx

(This Figure corresponds to Table 17 of the document, titled "European visitors by country of origin and discipline searched for").

Note: The distribution exclusively refers to online searches in the website www.mastersprotal.eu.

\# The information presented in the Figure (above) should be interpreted as follows: 28 percent of all searches in the website (for English-taught programmes) by people of French origin search for courses related to Business \& Economics.

\subsection{Tuition fees and Scholarships}

Another feature which has placed European countries on the radar of Indian students is the cost of higher education. The financial feasibility of pursuing higher education abroad is one of the main variables that determine their choice of destination. In this regard, several European countries have gained mileage as they charge considerably lower tuition fees. Additionally, there is another factor, which differentiates Germany and France from other countries. Unlike many host countries like the UK, or the US, Germany and France do not distinguish between domestic and international students and charge the same tuition fees for all students. This is in contrast with the UK, which charges considerably higher fees for international students, which can be up to three times the amount charged to domestic students (Lall, 2008). The differences in tuition rates for international students are often a reflection of differences in the national policies pursued by them.

In general, countries like the UK, the US and Australia charge substantially higher tuition fees from foreign students because they form a vital source of university revenues. Tertiary education involving foreign students is thus a commercial avenue for many of the well-known English-speaking host nations. On the contrary, most universities in Germany and France are state-owned/public universities (funded by the government) where education is highly subsidized and tuition rates are kept low to attract the best talent from around the world.

As high tuition rates considerably raise the expenditure associated with higher education abroad and place a number of students under financial strain, lower tuition rates offered by Germany and France indeed provide a strong incentive for many Indian students considering higher education abroad. 
A recently conducted study on the financial costs of pursuing higher education reported significant differences between countries with respect to the costs associated with higher education abroad. ${ }^{39}$ The study which ranked countries based on (multiple perspectives of) affordability of higher education found that the average cost of education was the lowest in France [\$585], followed by Germany [\$933]. The average living costs were $\$ 7462$ and $\$ 5317$, respectively, which were considerably lower than that in the US [\$9759], or the UK [\$9556]. An aggregate assessment of costs (which included educational and living costs, in addition to the (average) availability of government grants) revealed that Germany and France were considered as relatively more affordable destinations for higher education (as they ranked 3 and 7, respectively), compared to the UK, the US and Australia, which ranked much lower on the scale (at 11, 12 and 13, respectively). The fact that the study did not account for the difference between (domestic and international student) tuition rates in presenting the costs imply that Germany and France were cheaper destinations in absolute terms, and the disparity could be more magnified once the tuition rate differentials were taken into account. ${ }^{40}$

The tuition rates charged by international universities are crucial for Indian students as most students incur educational loans to finance their education, which consequently places them under an obligation to repay the loan. In this regard, lower tuition fees can make a significant difference to the financial impact of studying abroad.

Germany in particular has an advantageous position as education is subsidized by the government and hence, most universities charge minimal (limited to $€ 500$ per semester) or no tuition fees. ${ }^{41}$ Combining living costs, a year of study in Germany can usually cost nearly Rs. 0.6 million (Indian Rupees (INR)), which is in stark contrast to an equivalent period spent in the UK, which can cost a student up to Rs. 3 million. ${ }^{42}$ The tuition fees charged by the public universities in France are also comparatively reasonable. The tuition rates for courses (offered by public universities) vary across degrees and annual rates for engineering programmes were reported to be $€ 550$, whereas Master's programmes were priced at $€ 237$ (for the academic year 2010-11). ${ }^{43}$ Though the tuition fees charged by private universities in France can be substantially higher, they are more affordable compared to similar degrees in the UK or the US.

The results from the survey on Indian students in Europe also suggest that a number of Indian students are sensitive to the financial aspect of higher education. The survey found that 51.6 percent of all respondents in Germany cited lower costs of education as one of the reasons for choosing the host country, whereas this was a motivating factor for nearly 46 percent of all respondents in France.

Another study which compared the tuition fees charged by several countries for international students supports the above statement and found that France charged close to $€ 200$ whereas the rates in Germany were slightly higher and ranged between $€ 0$ and $€ 1000$ (for Bachelor's and Master's programmes), which were the lowest tuition rates charged by any of the major host countries. Not surprisingly, the UK charged the highest tuition fees which ranged between $€ 7000$ and $€ 16,000$ for Bachelor's courses, while Master's programmes were priced higher and ranged between $€ 6000$ and $€ 23,000 .^{44}$

\footnotetext{
39 This is a report titled Global Higher Education Rankings: An Affordability and Accessibility Comparative Perspective (2010) http://www.ireg-observatory.org/pdf/HESA_Global_Higher_EducationRankings2010.pdf (last accessed on 29.7.2012)

${ }^{40}$ For more information, refer to the Global Higher Education Rankings (2010) report. http://www.ireg-observatory.org/pdf/HESA_Global_Higher_EducationRankings2010.pdf(last accessed on 29.7.2012)

${ }^{41}$ http://newdelhi.daad.de/mainFrame/toGermany/masterstudiesingermany.pdf(last accessed on 11.5.2012)

42 http://www.universityworldnews.com/article.php?story=20111209195503978 (last accessed on 11.5.2012)

${ }^{43}$ Campus France (2011) guide for international students

${ }^{44}$ For more information, refer to the NUFFIC Report on International student flows titled, "Competing for the brightest minds”. http://www.nuffic.nl/en/news/latest-news/competing-for-the-brightest-minds (last accessed on 3.5.2012)
} 
In addition to lower tuition rates, Germany and France offer financial incentives to Indian students in the form of various scholarships and grants. In case of Germany, institutions like the German Academic Exchange Service (DAAD) and universities alike offer a wide range of financial aid. Recent reports find that nearly one in five, or 15-20 percent of all Indian students going to Germany receive some form of financial assistance. ${ }^{45}$ On similar lines, a number of scholarships offered by Campus France, the French Embassy and French universities are available to Indian students going to France. For instance, Campus France and the French Embassy offered nearly 400 scholarships in the academic year of 2010-11, and majority of them covered a part of the tuition fees (amounting to €615 per semester). Overall, nearly 12 percent to 15 percent of all Indian students in France receive some of financial aid. ${ }^{46}$

Thus, evidence suggests that the financial implications of pursuing higher education in Germany and France (in terms of lower tuition rates, educational costs and the availability of scholarships) is likely to be one of the main reasons why Indian students are choosing these relatively new destinations. ${ }^{47}$

In addition to the above, the number of partnerships between Indian universities and their French and German counterparts has also increased over time. Germany has traditionally focused on areas of Science, IT and Engineering and thus promoted the exchange of scientists between India and Germany. In fact, the exchange has intensified through a project undertaken by the Indian Department of Science and Technology (DST) and DAAD, which resulted in 120 new collaborations and an exchange of 900 scientists between India and Germany. ${ }^{48}$ Agreements between France and India have been established in the fields of Economics and Management, Humanities and Social Sciences, linguistic studies as well as scientific and Technology studies. Several partnerships have been established between Delhi University in India and French universities (such as Paris University) on areas of Nuclear Science, Chemistry and Nano sciences. ${ }^{49}$

\section{Constraints}

As seen in the previous section, the German and French education systems have incorporated features that have created a more conducive environment to receive international students. This has strengthened their international appeal and also attracted a favourable response from Indian students. However, certain challenges continue to exist for Indian students studying in Germany and France. The following analysis is based on the findings of a primary survey of Indian students in Europe and elaborates on certain features of the German/ French higher education systems which were found to affect their overall experience. ${ }^{50}$

\footnotetext{
${ }^{45}$ As per a discussion with a representative of DAAD in Germany

46 As per a discussion with a Campus France representative in Bangalore, India

${ }^{47}$ http://www.hindustantimes.com/HTEducation/Chunk-HT-UI-HTEducationSectionPage-OtherStories/Indian-enrolmentssoar-in-Germany/SP-Article1-798328.aspx (last accessed on 26.7.2012)

${ }^{48}$ Campus France (2010) report on India

${ }^{49}$ For more information on initiatives and scholarships, refer to an earlier paper on student mobility between India and Europe. http://www.india-eu-migration.eu/media/CARIM-India\%202012\%20-\%2012.pdf

50 The survey was conducted as part of a study on Indian students in Europe, and sampled Indian students studying in five European countries, namely, the UK, Germany, France, Italy and Spain. The results revealed similar trends in the difficulties faced by Indian pursuing higher education in Germany and France. A summary of the results pertaining to (Indian) students in Germany and France can be found in Table A.8 of Annexure 1. For a comprehensive summary of the survey results, refer to an earlier paper on Indian student mobility to Europe. http://www.india-eu-migration.eu/media/CARIM-India\%202012\%20-\%2012.pdf
} 


\subsection{Financial considerations}

The financial cost associated with higher education is undoubtedly one of the chief considerations for all internationally mobile students. It is a particularly important variable concerning Indian students and the results from the survey highlight the importance of the same. Not surprisingly, 84 percent of all respondents from Germany as well as France cited a high cost of living as one of the main issues faced during their stay. Despite (relatively) lower tuition rates, the living costs are considered to be high, as the monthly expenses range between $€ 800$ and $€ 1000$ in France. ${ }^{51}$ As a Master's programme in Germany or France is likely to cost a minimum of (INR) Rs. 0.6 million annually, the financial impact of studying in Germany or France is a non-negligible one for many Indian students.

\subsection{Cultural and Linguistic difference}

Within Europe, Germany and France are countries with strong historical linkages and a rich cultural legacy. Cultural identity is integral for the people of Germany and France and it assumes an important role in their society. However, this feature of the German and French society has the potential to create difficulties for international students. Not surprisingly, a number of prospective students from India considering Germany or France raise this issue and the results from the survey reflect this concern.

Nearly 75 percent of all respondents from Germany and 79.2 percent of respondents from France cited cultural differences as one of the main issues faced during their stay in Europe. For nearly half of the respondents in Germany and 61 percent of the respondents in France, inadequate language skills (and associated cultural challenges) were the main difficulty faced during their stay. Though this issue is likely to affect most non-European students, it poses a greater challenge for many Indian students due to the existing language barrier. While Indian students fulfill the minimum linguistic requirements on (or after) securing admission to a German or French university, their knowledge is often limited which consequently affects their ability to communicate and fully adapt to the German/French system.

According to a Postgraduate student (pursuing a Master's degree in Global Production Engineering) in Germany, sound knowledge of the German language is important because it affects an international student's chances of securing suitable employment and also helps one integrate with the German society. Inadequate knowledge of the local language is therefore regarded as a serious challenge for many Indians studying in Germany and France.

\subsection{Employment opportunities}

Results from the survey revealed that 50 percent of all respondents from France cited the possibility of overseas employment as one of the reasons for studying outside India, comparatively; fewer respondents from Germany (29 percent) cited this reason. Most Indian students would seek employment opportunities in the host country for two reasons. For one, a number of them view higher education abroad as a medium to acquire skills which are recognized internationally, which consequently increases their ability to compete in the international labour market. Thus, the very purpose of studying abroad is a means of finding suitable employment, which offers "good returns on their investment". ${ }^{52}$ However, as mentioned earlier, some students may also seek employment to repay the financial obligations undertaken in the form of educational loans. Such students usually seek employment for a short duration. However, the possibility of employment (post studies) remains a serious concern for several Indian (and international) students for a variety of reasons. A Postgraduate student (pursuing a Master's degree in Finance) in France stated that extending the student visa after

\footnotetext{
${ }^{51}$ www.campusfrance.org (last accessed on 12.5.2012) http://newdelhi.daad.de/mainFrame/toGermany/masterstudiesingermany.pdf (last accessed on 12.5.2012)

52

http://articles.economictimes.indiatimes.com/2011-05-01/news/29491210_1_indian-students-uk-visa-rules (last accessed on 12.5.2012)
} 
completing studies was a complicated process and this often affected an Indian student's chances of looking for employment. Indian students in Germany are likely to face a similar issue, as a Postgraduate student (pursuing a Master's degree in Real Estate Management) believed that adequate knowledge of the German language was essential for securing part-time as well as full-time employment in Germany.

\subsection{Regulations on Employment}

The legal regimes governing the post-study conditions for employment of international students is another factor of concern for foreign students in Germany and France. Under the current provision, international students in France are allowed a maximum period of six months (after the completion of studies) to find employment in France, whereas those in Germany are allowed up to one year for the same. However, these may be regarded as too preventive by some Indian students, as the survey results suggest that nearly all respondents (95.6 percent) in France cited stringent visa regulations (for employment) as one of the main challenges faced in France, whereas respondents from Germany cited this issue less frequently (71 percent).

\subsection{Unequal opportunities for foreign graduates}

The issue of employment is further complicated by other factors. In addition to legal constraints, Indian (and international) students may not always get an equal opportunity to apply for employment. Some Indian students who studied in France believed that there is a preference for French and other European nationals to fill vacancies in France. ${ }^{53}$ Yet another student stated that many employers could not immediately offer permanent positions to well-performing Indian interns, as the rules required the advertisement for the (permanent) job vacancy to be available online for a minimum period, before considering a non-EU national for the same. While it remains unclear whether this rule continues to exist, recruitment practices, which have limited the opportunities for international students, have had an unfavourable impact on Indian students seeking employment (in France) in the past.

However, some reports suggest that there may be realistic opportunities available for Indian students studying in France. With nearly 700 French companies operating in India and several Indian companies operating in France, there is likely to be a growing demand for skilled French-speaking Indian workers. ${ }^{54}$ According to a Campus France representative, the employment scenario is not as grim as often portrayed. She stated that though the possibility of employment (in France) was industry-specific, a number of Indians students were successfully recruited every year by French companies for vital positions in their local offices in India.

The employment scenario for Indian students in Germany is likely to be different, partially due to the economic conditions prevailing in Germany. For one, the presence of Indians in the German workforce is not a new phenomenon. As a result of the Green-card initiative undertaken by Germany (in 2000) to strengthen its Information Technology (IT) sector, nearly 5300 IT specialists from India were granted work permits. Venema (2004) found that India was by far the largest beneficiary of this initiative as over 31 percent of all Green cards issued by Germany were given to Indian professionals. ${ }^{55}$

\footnotetext{
53 This is indeed the case with most European countries, as employers (within the EU) must meet domestic search requirements which include advertising vacancies for a period of time before considering a non-EU national for the same.

54 http://institutfrancais.in/content/study-france (last accessed on 12.5.2012)

55 From its implementation in $1^{\text {st }}$ August, 2000 until 31 $31^{\text {st }}$ 2004, an aggregate of over 17,000 green cards were issued by Germany, of which, over 5,300 (or over 31 percent) were received by Indian professionals. For more information, see Venema (2004)
} 
However, the current rules in Germany on the employment of foreign graduates are complicated, unrealistic and reduce the opportunities available for Indian students. According to a senior executive in Germany, employing non-European workers may prove to be a time-consuming and costly venture for engineering firms, and the process is further complicated by bureaucratic barriers. Moreover, under the current rules, firms wanting to hire a foreign worker are first required to "prove that they (the firm) could not find someone suitable in the EU". The situation is further worsened by tall residency requirements, which allows visas to be issued (to non-EU residents) only if the (German) employer guarantees an annual wage of at least $€ 66,000$ (which is "over double the average annual salary" in Germany). ${ }^{56}$ The current provisions are therefore seen to have serious bottlenecks, which limit the probability of finding employment for many Indian students.

However, the recent adoption of a bill to launch the EU Blue Card, which provides "a new work and residence permit for international students", is expected to generate interest in students from India. ${ }^{57}$ The steady decline in Germany's demographic trend is likely to create a shortfall of nearly 6 million workers by 2030. ${ }^{58}$ Such an eventuality will have severe ramifications for the future productivity and growth of the German economy, and coupled with the existing shortage of skilled labour in Germany, the urgency to attract skilled immigrants is increasingly being stressed upon. Among other features, the provisions of the bill are expected to offer "better prospects of gaining residency for foreign graduates, and lower income requirements for highly skilled workers (reduced from a minimum annual income of $€ 66,000$ to $€ 44,000$ )" ${ }^{59}$ Thus, by lowering residency requirements for international graduates and workers, the initiative is expected to attract more qualified immigrants and help Germany address the serious issue of shortage of skilled workers. ${ }^{60}$ While the Blue Card may prove to be a critical development in favour of Indian students (and other foreign graduates) in Germany, the effectiveness of such an undertaking is yet to be seen ${ }^{61}$ Nonetheless, this may raise the number of Indian students participating in the German workforce in the near future.

\section{Competition from Emerging Destinations of Higher Education}

In addition to identifying the constraints operating on Indian students in Germany and France, it is necessary to recognize issues, which may affect the attractiveness of these markets. In light of recent developments, the most challenging aspect for Germany as well as France is likely to be the element of competition in the international higher education market.

The dynamics of international student mobility are changing fast and this process has been facilitated by the entry of new host nations offering higher education on a global scale. In recent years, a number of factors have shifted the focus favourably on destinations like New Zealand, Canada, China and Singapore. ${ }^{62}$ Though Germany and France have done well to attract the attention of Indian students, retaining their market share will be challenging, in the face of growing competition from a variety of host countries.

\footnotetext{
56 http://www.reuters.com/article/2011/08/12/us-germany-labour-immigration-idUSTRE77B1S120110812 (last accessed on 12.5.2012)

${ }^{57}$ http://www.hindustantimes.com/HTEducation/Chunk-HT-UI-HTEducationSectionPage-OtherStories/Indian-enrolmentssoar-in-Germany/SP-Article1-798328.aspx (last accessed on 12.5.2012)

58 http://www.dw.de/dw/article/0,,15778948,00.html (last accessed on 12.5.2012)

${ }^{59}$ http://www.hindustantimes.com/HTEducation/Chunk-HT-UI-HTEducationSectionPage-OtherStories/Indian-enrolmentssoar-in-Germany/SP-Article1-798328.aspx (last accessed on 12.5.2012)

${ }^{60}$ http://www.dw.de/dw/article/0,,15569182,00.html (last accessed on 12.5.2012)

${ }^{61}$ http://www.india.diplo.de/Vertretung/indien/en/_pr/Business_News/Blue_card__bill.html (last accessed on 12.5.2012)

${ }^{62} \mathrm{http} / / /$ www.theinternationalstudentrecruiter.com/india-sending-and-competing/ (last accessed on 12.5.2012)
} 
A limitation of the (UNESCO) statistics presented earlier is the unavailability of data from 2010 onwards. As significant changes in student preferences have been recorded since the same year, much of the following discussion is based on averages reported in the media.

Though student flows from India to Germany and France has shown an upward trend in recent years, it is important to note that alongside Germany and France, new English-speaking destinations like New Zealand and Canada have also intensified their student recruitment efforts in India. Canada in particular has gained serious credibility in the Indian market by promoting itself as a destination with lower tuition rates and living costs, in addition to relaxed visa requirements. The regulation on post-study work permits is arguably Canada's most attractive feature, as foreign students in Canada are allowed up to a three-year work visa on completion of their studies. Evidently, such policies have made a strong impact on student mobility, as Canada issued nearly 12,000 student visas to Indians in 2010, compared to 3,152 in 2008. ${ }^{63}$ A similar scenario is seen in case of New Zealand, where employment prospects are possibly one of the key reasons, which attracts Indian students to the country. With over 3400 student visas issued to Indian students in the previous year, their presence in New Zealand has grown steadily since 2007. In fact, recent reports suggest "India has become the largest source country for new international students in New Zealand" ${ }^{64}$ Notably, India is the secondlargest source country of skilled migrants in New Zealand, with a market share of 13 percent. ${ }^{65}$

One of the reasons behind the success of Canada and New Zealand is the mutual gain that results from recruiting Indian students. While Indian students benefit from the various academic and employment incentives provided by the host countries; their presence, in turn, helps Canada and New Zealand address their respective labour market shortages. ${ }^{66}$

Germany and France also face competition from emerging Asian host countries like Singapore, Japan, Taiwan and China. While Singapore hosts 4000 Indian companies and offers strong prospects of employment for highly skilled migrants from India, Taiwan hosts nearly 600 doctorate students from India in the field of Chemistry and Chemical Engineering. Though these are upcoming markets and currently attract fewer Indian students, their geographical proximity to India and aggressive marketing in India has increased the options available to several students.

The trends outlined above clearly imply that emerging markets are able to influence student flows from India by offering a combination of incentives. Not only do they address the financial feasibility of pursuing higher education abroad, they also offer long-run prospects in the form of employment in upcoming Asian economies. In comparison to these markets, the advantages of studying in Germany and France (among other European markets) may well fall short of student expectations.

\section{Conclusion}

It is seen from the preceding analysis that the flow of Indian students going abroad for higher education is shaped by a variety of factors. Undoubtedly, Germany and France are attracting more Indian students each year and a number of initiatives undertaken by higher education institutions have encouraged this trend. However, whether the trend is likely to continue depends on a number of external factors.

\footnotetext{
${ }^{63}$ http://www.deccanherald.com/content/179460/indian-students-look-towards-canada.html (last accessed on 13.5.2012)

${ }^{64}$ http://articles.economictimes.indiatimes.com/2011-01-31/news-by-industry/28423697_1_indian-students-internationalstudents-largest-source (last accessed on 13.5.2012)

${ }^{65}$ http://www.nzherald.co.nz/nz/news/article.cfm?c_id=1\&objectid=10783070 (last accessed on 13.5.2012)

${ }^{66}$ Canada is already a well-known destination for employment prospects as its labour force has the largest share of foreign workers (nearly 26 percent)
} 
With regard to Indian students, the most challenging aspect for European markets will be the element of competition. The international student landscape is changing fast due to an increasing number of host countries competing for international students. Though Germany and France have emerged as cost-effective destinations for Indian students in recent years, the competition for Indian students will intensify in the future. Even though they offer various incentives to international students, these may not be sufficient, as the experience for most students in Germany and France remains confined to the 'student life', with few realistic long-term opportunities.

The new entrants, on the other hand, have incentivized higher education by merging the student route with the employment route and Indian students have responded positively to such inducements. This implies that Germany and France, in effect, face competition from two prominent groups; the leading host countries like the US, the UK and Australia (which is in the process of reviving its market position in India) which continue to receive a major share of Indians, and emerging destinations like Canada and New Zealand which offer promising post-study employment prospects.

Aligning expectations will be crucial in determining student flows between European countries and India. The current German and French education policies are well designed to attract international students, but not necessarily retain them. In this regard, these markets are perceived to have a shortterm interest in Indian students. However, students from India are likely to choose countries that offer a combination of short-run and long run prospects. Between the two regions, therefore, there exists a misalignment of expectations, which is likely to divert the attention of Indian students towards countries that offer more favourable conditions.

Expanding the set of opportunities available to Indian students can help Germany and France improve their attractiveness as higher education destinations. For one, it will be important to address the linguistic challenges faced by Indian students in Germany and France. One of the difficulties often cited by many Indian students was insufficient knowledge of the German/French language, which affected their chances of finding suitable employment. A possible way to reduce this difficulty could be to incorporate additional training programmes in the German/French languages during the course of the study, which will help a number of foreign graduates improve their proficiency and also the scope of their employability in the German/French labour market.

Offering feasible long-term prospects to foreign graduates will be another way to improve the attractiveness of host countries. Offering long-term incentives may be a mutually beneficial strategy especially in case of Germany, which is experiencing a range of problems meeting its labour market requirements. Faced with a shortage of labour supply and skills-mismatch in service-oriented sectors, it will be important to implement measures that increase labour participation rates for Germany (Constant and Tien, 2011) ${ }^{67}$ Coupled with a demographic decline due to an ageing population (it is estimated that only 47.7 percent of the German population will be in the labour force by 2020) and aggravated by high levels of net emigration from Germany, it is believed that medium and long-term migration will be important in addressing the demographic challenges in Germany (Sachverstandigrat, 2011). ${ }^{68}$

${ }^{67}$ For a detailed analysis of the labour shortages experienced in Germany, refer to a Research Report titled, Germany Immigration Policy and Labour Shortages (Constant and Tien, 2011) http://www.iza.org/en/webcontent/publications/reports/report_pdfs/iza_report_41.pdf

${ }^{68}$ See Constant and Tien (2011). In 2008, 50 percent of the German population was estimated to be in the labour force, with the largest share of workers (24.5 percent) aged between 30 and 50 years, and only 10 percent aged between 20 and 30 years of age. The population in labour force is expected to drop to 47.7 percent by 2020, and to 42.1 percent by 2035 . The average age of the workforce is also expected to increase, with 19.3 percent of the working population (which will comprise 47.7 percent of the German population) aged between 50 and 65 years by 2020. For more information, see Constant and Tien (2011)

The net migration in Germany has declined for a few years and was recorded to be -30,000 in 2009, implying that there was a net outflow of people from Germany in 2009. Constant and Tien (2011) find that several Germany leave Germany and move to other developed countries like Switzerland and the USA. 
Germany's response to the ongoing problem of labour shortages is the Blue Card initiative, which is aimed at attracting highly skilled workers to Germany and one that will allow foreign graduates (of German universities) unrestricted access to the German labour market (for positions relevant to their qualifications). An important feature of this Bill is the minimum (annual) income requirement for permanent settlement of qualified immigrants, which has been lowered from $€ 66,000$ to $€ 48,000$. $^{69}$ While this implies brighter prospects for international students and is likely to have a positive bearing on the flow of Indian students, the income requirement may pose a challenge, as the new minimum requirement of $€ 48,000$ is nearly 1.5 times the average (annual) salary in Germany. Thus, one way of improving the effectiveness of the Blue Card Bill (and consequently the attractiveness of Germany for higher education), could be to lower the minimum income requirement, as the current level is relatively high and may be unattainable for many Indian graduates.

In the light of a short-term approach to international-student policy, emerging competitors and an ongoing economic crisis in Europe, the future of Indian student flows to Germany and France appears uncertain. While current trends are positive, measures such as special language-training for foreign students and careful implementation of policy initiatives like the Blue Card (implemented by Germany) will be essential in securing a sizeable share of the Indian student market. ${ }^{70}$

\footnotetext{
${ }^{69}$ http://www.india.diplo.de/Vertretung/indien/en/_pr/Business__News/Blue_card__bill.html (last accessed on 30.7.2012)

${ }^{70}$ http://www.india.diplo.de/Vertretung/indien/en/_pr/Business_News/Blue_card_bill.html (last accessed on 30.7.2012).
} 


\section{ANNEXURE 1}

Table A.1 Internationally mobile students

\begin{tabular}{|l|r|r|r|r|r|}
\hline YEAR & $\begin{array}{c}\text { World Total } \\
\text { (in Mln) }\end{array}$ & $\begin{array}{c}\text { Annual } \\
\text { Growth (\%) }\end{array}$ & $\begin{array}{c}\text { International } \\
\text { students in } \\
\text { Europe (in Mln) }\end{array}$ & $\begin{array}{c}\text { International } \\
\text { students in } \\
\text { Europe (Share in } \\
\text { World Total) }\end{array}$ & $\begin{array}{c}\text { Annual } \\
\text { Growth (\%) }\end{array}$ \\
\hline 1999 & 1.635 & & 0.86 & $52.6 \%$ & \\
\hline 2000 & 1.757 & 7.40 & 0.912 & 51.9 & 6.00 \\
\hline 2001 & 1.834 & 4.40 & 0.98 & 53.4 & 7.40 \\
\hline 2002 & 2.143 & 16.80 & 1.064 & 49.7 & 8.60 \\
\hline 2003 & 2.421 & 13.00 & 1.208 & 49.9 & 13.50 \\
\hline 2004 & 2.489 & 2.80 & 1.246 & 50.1 & 3.20 \\
\hline 2005 & 2.543 & 2.10 & 1.274 & 50.1 & 2.20 \\
\hline 2006 & 2.617 & 2.90 & 1.297 & 49.6 & 1.80 \\
\hline 2007 & 2.831 & 8.20 & 1.358 & 48.0 & 4.70 \\
\hline 2008 & 2.944 & 4.00 & 1.421 & 48.3 & 4.70 \\
\hline 2009 & 3.109 & 5.60 & 1.483 & 47.7 & 4.40 \\
\hline
\end{tabular}

Source: UNESCO database on International students at tertiary level (ISCED 5 and 6)

http://stats.uis.unesco.org/unesco/ReportFolders/ReportFolders.aspx (last accessed on 2.5.2012)

Table A.2 Share of (total) international students in major Host Countries (\%)

\begin{tabular}{|l|r|r|r|r|r|r|r|r|r|}
\hline & \multicolumn{1}{|c|}{ USA } & UK & Australia & France & Germany & Canada & $\begin{array}{c}\text { New } \\
\text { Zealand }\end{array}$ & Japan & Others \\
\hline & & & & & & & & & \\
\hline $\mathbf{1 9 9 8}$ & 47.0 & 22.9 & 11.9 & & & 3.1 & 0.6 & 6.1 & 8.4 \\
\hline $\mathbf{1 9 9 9}$ & 27.6 & 14.2 & 7.2 & 8.0 & 10.9 & 2.0 & 0.4 & 3.5 & 26.2 \\
\hline $\mathbf{2 0 0 0}$ & 27.0 & 12.7 & 6.0 & 7.8 & 10.6 & 2.1 & 0.5 & 3.4 & 29.9 \\
\hline $\mathbf{2 0 0 1}$ & 25.9 & 12.3 & 6.6 & 8.0 & 10.9 & 2.3 & 0.6 & 3.5 & 29.9 \\
\hline $\mathbf{2 0 0 2}$ & 27.2 & 10.6 & 8.4 & 7.7 & 10.2 & 2.3 & 0.8 & 3.5 & 29.2 \\
\hline $\mathbf{2 0 0 3}$ & 24.2 & 10.5 & 7.8 & 9.2 & 9.9 & 2.4 & 1.1 & 3.6 & 31.3 \\
\hline $\mathbf{2 0 0 4}$ & 23.0 & 12.1 & 6.7 & 9.5 & 10.5 & 2.6 & 1.7 & 4.7 & 29.2 \\
\hline $\mathbf{2 0 0 5}$ & 23.2 & 12.5 & 7.0 & 9.3 & 10.2 & 2.7 & 1.6 & 5.0 & 28.5 \\
\hline $\mathbf{2 0 0 6}$ & 22.3 & 12.6 & 7.1 & 9.5 & 7.9 & 2.6 & & 5.0 & 33.0 \\
\hline $\mathbf{2 0 0 7}$ & 21.0 & 12.4 & 7.5 & 8.7 & 7.3 & 3.3 & 1.2 & 4.4 & 34.1 \\
\hline $\mathbf{2 0 0 8}$ & 21.2 & 11.6 & 7.8 & 8.3 & 6.4 & 3.2 & 1.1 & 4.3 & 36.1 \\
\hline $\mathbf{2 0 0 9}$ & 21.2 & 11.9 & 8.3 & 8.0 & 6.4 & & 1.2 & 4.2 & 38.7 \\
\hline
\end{tabular}

Source: UNESCO database on International students at tertiary level (ISCED 5 and 6) http://stats.uis.unesco.org/unesco/ReportFolders/ReportFolders.aspx (last accessed on 2.5.2012) 
Table A.3 Main Source Countries (Percentage Share in Total International students) (\%)

\begin{tabular}{|l|r|r|r|r|r|}
\hline \multicolumn{2}{|c|}{2000} & \multicolumn{2}{c|}{$\mathbf{2 0 0 5}$} & \multicolumn{2}{c|}{$\mathbf{2 0 0 9}$} \\
\hline $\begin{array}{c}\text { Country of } \\
\text { Origin }\end{array}$ & $\begin{array}{c}\text { Share } \\
(\%)\end{array}$ & $\begin{array}{c}\text { Country of } \\
\text { Origin }\end{array}$ & $\begin{array}{c}\text { Share } \\
(\%)\end{array}$ & $\begin{array}{c}\text { Country of } \\
\text { Origin }\end{array}$ & $\begin{array}{c}\text { Share } \\
(\%)\end{array}$ \\
\hline & & & & & China \\
\hline China & 6.6 & China & 15.6 & India & 15.9 \\
\hline Korea & 4.0 & India & 5.4 & Korea & 4.0 \\
\hline Greece & 3.6 & Korea & 3.9 & Germany & 3.0 \\
\hline Japan & 3.4 & Japan & 2.5 & Malaysia & 1.7 \\
\hline Germany & 3.0 & Germany & 2.2 & & \\
\hline
\end{tabular}

Source: UNESCO database on International students at tertiary level (ISCED 5 and 6)

http://stats.uis.unesco.org/unesco/ReportFolders/ReportFolders.aspx (last accessed on 1.11.2011)

Table A.4 Distribution of Indian students across Host countries (\%)

\begin{tabular}{|l|c|c|c|c|c|c|c|c|}
\hline Year & USA & UK & Australia & Germany & France & Canada & New Zealand & Others \\
\hline $\mathbf{1 9 9 9}$ & 72.9 & 8.3 & 7.8 & 2.1 & 0.3 & 1.7 & 0.2 & 6.7 \\
\hline $\mathbf{2 0 0 0}$ & 73.4 & 7.4 & 8.6 & 2.4 & 0.3 & 1.8 & 0.4 & 5.6 \\
\hline $\mathbf{2 0 0 1}$ & 80.8 & 7.3 & & 2.4 & 0.4 & 2.2 & 0.6 & 6.2 \\
\hline $\mathbf{2 0 0 2}$ & 73.3 & 6.6 & 10.5 & 2.4 & 0.3 & 2.0 & 1.0 & 3.9 \\
\hline $\mathbf{2 0 0 3}$ & 67.4 & 9.4 & 11.2 & 3.1 & 0.6 & 2.2 & 1.1 & 5.0 \\
\hline $\mathbf{2 0 0 4}$ & 63.3 & 11.6 & 12.5 & 3.4 & 0.4 & 2.2 & 1.3 & 5.3 \\
\hline $\mathbf{2 0 0 5}$ & 60.9 & 12.1 & 14.9 & 3.1 & 0.4 & 2.0 & 1.1 & 5.5 \\
\hline $\mathbf{2 0 0 6}$ & 58.1 & 14.1 & 16.4 & 2.6 & 0.5 & 1.3 & & 6.9 \\
\hline $\mathbf{2 0 0 7}$ & 55.6 & 15.5 & 15.9 & 2.2 & 0.6 & 2.1 & 1.6 & 6.5 \\
\hline $\mathbf{2 0 0 8}$ & 53.6 & 14.7 & 15.0 & 1.8 & 0.6 & 2.0 & 2.3 & 9.9 \\
\hline $\mathbf{2 0 0 9}$ & 53.2 & 17.9 & 13.9 & 1.7 & 0.7 & & 3.0 & 9.6 \\
\hline
\end{tabular}

Source: UNESCO database on International students at tertiary level (ISCED 5 and 6) http://stats.uis.unesco.org/unesco/ReportFolders/ReportFolders.aspx (last accessed on 2.5.2012)

Table A.5 International students in Germany: Top sending countries: 2008-09

\begin{tabular}{|l|r|r|r|r|r|r|r|r|r|r|r|}
\hline $\begin{array}{l}\text { Place of } \\
\text { Origin }\end{array}$ & China & Turkey & Russia & Poland & Bulgaria & Ukraine & Austria & Italy & Morocco & France & All Others \\
\hline $\begin{array}{l}\text { Percent of } \\
\text { Total }\end{array}$ & $10.30 \%$ & $9.30 \%$ & $5.20 \%$ & $5.10 \%$ & $4.00 \%$ & $3.60 \%$ & $2.90 \%$ & $2.90 \%$ & $2.80 \%$ & $2.50 \%$ & $51.40 \%$ \\
\hline
\end{tabular}

Source: Institute of International Education

http://www.iie.org/Services/Germany/International-Students-In-Germany 
Table A.6 Share of Indian students in France

\begin{tabular}{|l|r|r|r|}
\hline & International Students- Total & Indian Students in France & Share of Indian students \\
\hline $\mathbf{2 0 0 0}$ & 137085 & 185 & $0.1 \%$ \\
\hline $\mathbf{2 0 0 1}$ & 147402 & 239 & $0.2 \%$ \\
\hline $\mathbf{2 0 0 2}$ & 165437 & 309 & $0.2 \%$ \\
\hline $\mathbf{2 0 0 3}$ & 221567 & 625 & $0.3 \%$ \\
\hline $\mathbf{2 0 0 4}$ & 237587 & 494 & $0.2 \%$ \\
\hline $\mathbf{2 0 0 5}$ & 236518 & 502 & $0.2 \%$ \\
\hline $\mathbf{2 0 0 6}$ & 247510 & 717 & $0.3 \%$ \\
\hline $\mathbf{2 0 0 7}$ & 246612 & 891 & $0.4 \%$ \\
\hline $\mathbf{2 0 0 8}$ & 243436 & 1038 & $0.4 \%$ \\
\hline $\mathbf{2 0 0 9}$ & 249143 & 1252 & $0.5 \%$ \\
\hline
\end{tabular}

Source: UNESCO database on International students at tertiary level (ISCED 5 and 6)

http://stats.uis.unesco.org/unesco/ReportFolders/ReportFolders.aspx (last accessed on 2.11.2011)

Table A.7 International students in France: Top sending countries: 2007-08

\begin{tabular}{|l|r|r|r|r|r|r|r|r|r|r|r|}
\hline $\begin{array}{l}\text { Place of } \\
\text { Origin }\end{array}$ & Morocco & Algeria & China & Tunisia & Senegal & Germany & Cameroon & Lebanon & Italy & Vietnam & All Others \\
\hline $\begin{array}{l}\text { Percent of } \\
\text { Total }\end{array}$ & $8.60 \%$ & $7.20 \%$ & $7.00 \%$ & $3.70 \%$ & $3.40 \%$ & $2.40 \%$ & $1.90 \%$ & $1.90 \%$ & $1.70 \%$ & $1.70 \%$ & $60.50 \%$ \\
\hline
\end{tabular}

Source: Institute of International Education

http://www.iie.org/Services/France/International-Students-In-France

Table A.8 Primary Survey-Summary of Results (Percentage distribution (\%))

\begin{tabular}{|c|c|c|c|}
\hline \multicolumn{2}{|r|}{ Country } & Germany & France \\
\hline Sample size & Total $=116$ & 26.72 & 20.69 \\
\hline \multirow{2}{*}{ Current Status } & Student & 77.4 & 91.7 \\
\hline & Employed & 22.6 & 8.3 \\
\hline \multirow{3}{*}{ Funding } & Scholarship & 19.4 & 29.2 \\
\hline & Educational Loan & 71.0 & 41.7 \\
\hline & A combination of both & 9.7 & 29.2 \\
\hline \multirow{5}{*}{$\begin{array}{l}\text { Reasons for studying } \\
\text { outside India * }\end{array}$} & International Exposure & 87.1 & 95.8 \\
\hline & Employment overseas & 29.0 & 50.0 \\
\hline & Migrate overseas & 6.5 & 41.7 \\
\hline & $\begin{array}{l}\text { Lack of institutions/excessive competition } \\
\text { in India }\end{array}$ & 38.7 & 16.7 \\
\hline & A foreign degree is worth more & 32.3 & 4.2 \\
\hline \multirow{6}{*}{$\begin{array}{l}\text { Reasons for choosing the } \\
\text { Host country (over other } \\
\text { European countries)* }\end{array}$} & Good quality of education & 74.2 & 79.2 \\
\hline & Prior knowledge of the language & 3.2 & 8.3 \\
\hline & Cheaper education & 51.6 & 45.8 \\
\hline & $\begin{array}{c}\text { Employment } \\
\text { opportunities in host country }\end{array}$ & 38.7 & 25.0 \\
\hline & Lower costs of living & 6.5 & 4.2 \\
\hline & Relaxed visa norms & 6.5 & 16.7 \\
\hline \multirow{4}{*}{$\begin{array}{c}\text { Challenges faced while } \\
\text { studying in the Host } \\
\text { country* }\end{array}$} & Cultural differences & 74.2 & 79.2 \\
\hline & Strict student visa norms & 67.7 & 54.2 \\
\hline & Strict visa regulations for employment & 71.0 & 95.8 \\
\hline & High cost of living & 83.9 & 83.3 \\
\hline
\end{tabular}

Source: Primary survey of Indian students in Europe

Note: $\left(^{*}\right)$ Refers to questions for which each respondent could choose multiple options. 
Figure A.1 Number of Institutions offering English-taught programmes in selected European Countries

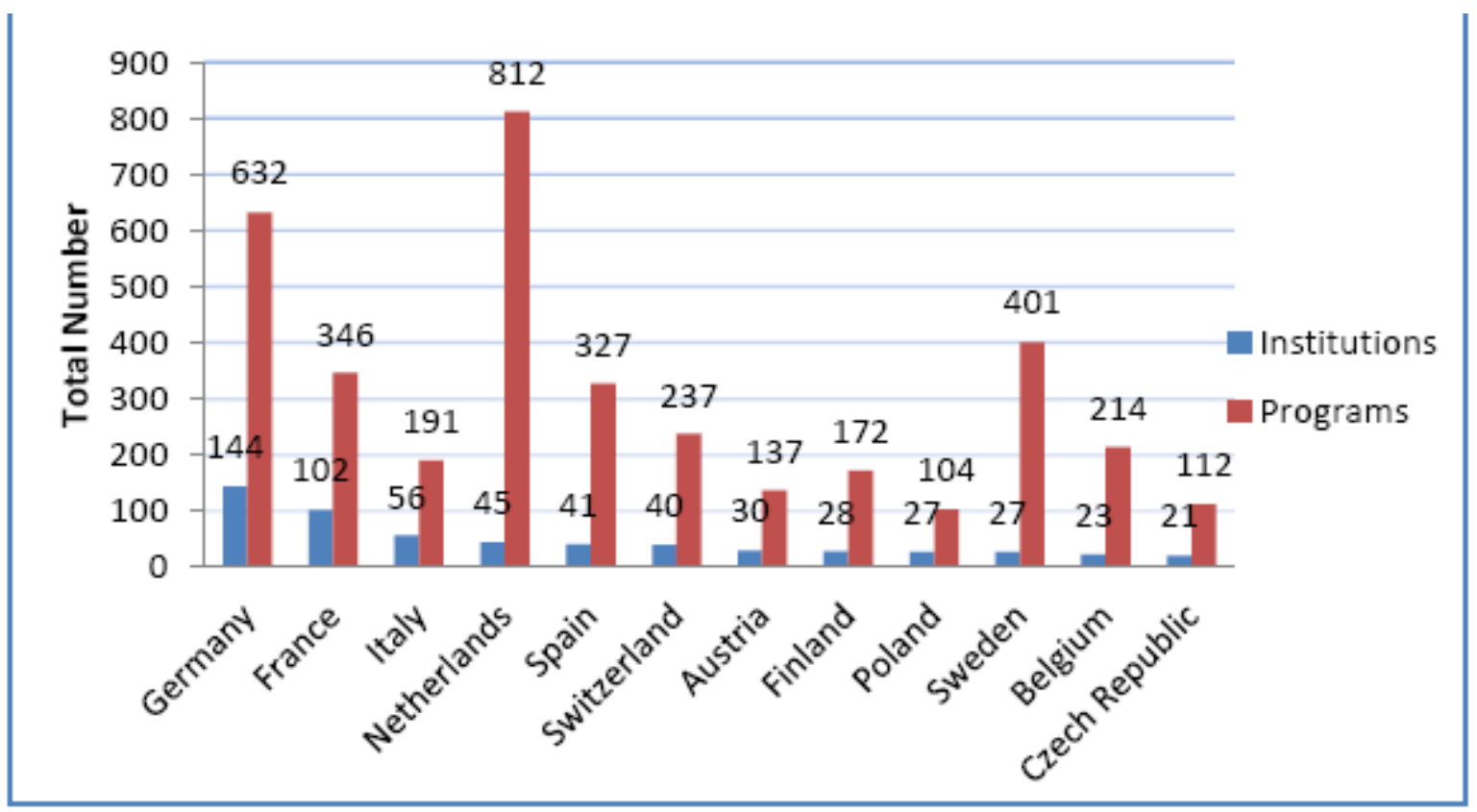

Source: Reproduced from an Institute of International Education (IIE) report titled, "English-taught programmes in Europe: New findings on Supply and Demand”. www.iie.org/Research.../English-Language-Masters-Final.ashx

(This Figure corresponds to Table 3 in the document, titled "Institutional Participation, number of Institutions offering English-Taught Master’s Programs and Total number of Programs”).

Note: The distribution exclusively refers to online searches in the website www.mastersprotal.eu.

\# The information presented in the Figure (above) should be interpreted as follows: In the duration of the study (2010-2011), 144 institutions in Germany offered (an aggregate of) 632 programmes taught in English. 


\section{Bibliography}

Bouwel, L.V., Veugelers.R. (2009). The determinants of Student Mobility in Europe: The quality dimension.

Constant, A.F and Tien, B.N. (2011). Germany's Immigration Policy and Labour Shortages. IZA Research Report No. 41.

http://www.iza.org/en/webcontent/publications/reports/report_pdfs/iza_report_41.pdf

Gottschlich, P. M.A. (2007). The Indian Diaspora in Germany.

http://www.wiwi.uni-

rostock.de/fileadmin/Institute/IPV/Lehrstuehle/Internationale_Politik/Pierre_Gottschlich/Gottschlic h_-_The_Indian_Diaspora_in_Germany.pdf

Hawthorne, L. (2008). The Growing Global Demand for Students as Skilled Migrants. Washington, DC: Migration Policy Institute.

Lall, Dr. M. (2008) Indian students in Europe: Trends, constraints and prospects, living in 'the age of migration"', briefing paper for the European Network of Contemporary Academic Research on India.

Marginson, S. (2006). OECD Report titled Globalization and Higher Education. http://www.oecd.org/innovation/researchandknowledgemanagement/37552729.pdf

Mukherjee, S., Chanda. R (2012). Indian Student Mobility to Selected European Countries- An Overview. Working Paper No. 365, Indian Institute of Management, Bangalore.

Musselin, C. (2004). Towards a European Academic Labour Market? Some Lessons Drawn from Empirical Studies on Academic Mobility. Higher Education, 48(1), 55-78.

Nuffic Report (2012): Competing for the brightest minds? http://www.nuffic.nl/en/news/latest-news/competing-for-the-brightest-minds

Organization for Economic Co-operation and Development (OECD) (2011) Education at a Glance, 2011: OECD Indicators http://www.oecd.org/dataoecd/61/2/48631582.pdf .Last accessed on 1.11.2011.

Theichler, U. (2009) Internationalization of Higher Education: European Experiences, Asia Pacific Education Review, Vol. 10, No. 1, pages 93-106.

Usher, A., Medow. J. (2010) Global Higher Education Rankings (2010): Affordability and Accessibility in Comparative Perspective. http://www.ireg-observatory.org/pdf/HESA_Global_Higher_EducationRankings2010.pdf

Venema, Mathias. (2004). Green Card for foreign IT professionals. Research report commissioned by the Federal Ministry of Economics and Work. Offenbach: MARPLAN

White, M.B, Rest E.V. (2012). English-Master’s Programs in Europe: New Findings on Supply and Demand. Report published by the Centre for Academic Mobility Research, Institute of International Education (IIE).

http://www.iie.org/en/Research-and-Publications/Publications-and-Reports/IIE-Bookstore/EnglishLanguage-Masters-Briefing-Paper

OECD Report on International Migration Outlook, 2011 http://www.wiso.unihamburg.de/fileadmin/vwl/aussenhandel/internationalewirtschaftsbeziehungen/Hauptstudium/Migr ation/WiSe2011_12/oecd_2011.pdf . Last accessed on 1.11.2011. 


\section{Data sources:}

Statistics on international student flows have been sourced from the following databases:

1. UNESCO Statistics on Education (International flow of mobile students at the tertiary level) http://stats.uis.unesco.org/unesco/TableViewer/tableView.aspx?ReportId=171

2. Federal Statistical Office, Germany (For statistics on Indian students in Germany) www.eds-destatis.de/en_index.php

3. Institute of International Education (IIE): Open Doors Data on International students http://www.iie.org/en/Research-and-Publications/Open-Doors/Data 